\title{
Sağlıklı Kent Bağlamında Çocuk Parklarındaki Oyun Alanları Analizi: Eskişehir Kenti Örneği
}

\author{
Elif Atıc1 ${ }^{1}$ \\ ORCID: 0000-0001-7163-2660
}

\author{
Ayşen Çelen Öztürk 2 \\ ORCID: 0000-0002-1821-2402
}

Öz

Çocukluk dönemi, bireyin hayatı anlamlandırmaya başladığı, karakterine yön verdiği ilk dönemdir. Bu dönemin sağlıklı bir şekilde geçirilmesi hem birey hem de toplum açısından önemlidir. Sağlıklı bir kent için ihtiyaçların karşılanması gerekir. Bu sebeple çocuk oyun alanlarının tasarlanması să̆lıklı kent için gerekli bir adımdır. Sağlıklı kent kriterleri bağlamında çocuk oyun alanlar Eskişehir kent merkezi üzerinden incelenmiştir. Nitel araştırma olarak betimsel araştırma bağlamında örnek olay kapsamındadır. En son 2006 yılında Eskişehir'de çocuk oyun alanları ile ilgili yapılan bir çalışma (Uz ve Çabuk, 2006) bulunmaktadır. 2006-2020 yılları arasında kent merkezindeki çocuk oyun alanlar ele alınmıştır. Mevcutta var olan geleneksel oyun alanlarının, sadece basit fiziksel aktivitelere yönelik olduğu görülmüştür. Çocuklarm yaratıcılık, keşfetme ve deneyimleme ihtiyaçlarına cevap verebilecek çeşitlilikte, farklılıkta ve yeteri kadar donanımda olmadı̆̆ı saptanmıştır. Sonuç olarak, Eskişehir kent merkezinde bulunan çocuk oyun alanları analiz edilerek, "Sağlıklı Kent" kavramına göre ideal tasarım kriterlerine uygunlukları irdelenmiş, bu alanların geliştirilmesi için öneriler sunulmuştur.

Anahtar Kelimeler: Sağlıklı kent, kentte çocuk olmak, çocuk oyun alanı, Eskişehir.

\footnotetext{
${ }^{1}$ Araştırma Görevlisi, Eskişehir Osmangazi Üniversitesi Mimarlık Bölümü, elifatici.026@gmail.com

2 Profesör Doktor, Eskişehir Osmangazi Üniversitesi Mimarlık Bölümü, acozturk@gmail.com

idealkent (c) Kent Araştırmaları Dergisi (Journal of Urban Studies) 


\title{
Analysis of Playgrounds in Children's Park in The Context of Healthy City: Example of Eskisehir City
}

\author{
Elif Atıc1 ${ }^{3}$ \\ ORCID: 0000-0001-7163-2660
}

\author{
Ayşen Çelen Öztürk 4 \\ ORCID: 0000-0002-1821-2402
}

\begin{abstract}
Childhood is the first period in which an individual begins to make sense of life and gives direction to his character. Passing this period in a healthy way is important for both the individual and the society. Needs must be met for a healthy city. For this reason, the design of children's playgrounds is a necessary step for a healthy city. In the context of healthy city criteria, children's playgrounds were examined through Eskişehir city center. As a qualitative research, it is within the scope of the case study in the context of descriptive research. There is a study (Uz and Çabuk, 2006) about children's playgrounds in Eskişehir in 2006. Between 2006 and 2020, children's playgrounds in the city center were discussed. It has been observed that the existing traditional playgrounds are for simple physical activities only. It has been determined that children are not in diversity, diversity and adequately equipped to meet their creativity, exploration and experience needs. As a result, children's playgrounds in the city center of Eskişehir were analyzed, and their compliance with the ideal design criteria according to the concept of "Healthy City" was examined, and suggestions were presented for the development of these areas.
\end{abstract}

Keywords: Healthy city, being a child in the city, children's playground, Eskişehir.

\footnotetext{
${ }^{3}$ R.A., Eskişehir Osmangazi University Department of Architecture, elifatici.026@gmail.com

${ }^{4}$ Prof. Dr., Eskişehir Osmangazi University Department of Architecture, acozturk@gmail.com 


\section{Giriş}

Toplumdaki her bireyin olduğu gibi çocukların da şehirden faydalanma hakkı vardır. Kentsel çevrelerin kalitesine odaklanan araştırma ve uygulamaların yanı sıra, kentsel politikaya hak temelli bir yaklaşımın sergilenmesi, çocukların karar verme süreçlerine katılmasına firsat oluşturacaktır (Brown, vd., 2019, s. 3). Bu konuyu Harvey (2015, s. 44): şehir hakkı olarak ifade ederek şu şekilde belirtmektedir Şehrin sunduklarından faydalanmanın yanı sıra, şehri istediğimiz şekilde değiştirmek şehir hakkının getirisidir. İnsan şehrini inşa ederken aslında kendisini de inşa etmektedir. Bu sebeple nasıl bir şehir istediğimiz nasıl bir insan istediğimizle örtüşmektedir (Harvey, 2015, s. 44). Dolayısıyla çocukluk döneminde oluşan karakter, bireyin yetişkinlik dönemini etkilediği için, nasıl bir insan istediğimiz sorusu nasıl bir çocukluk geçirildiğiyle yakından ilişkilidir.

Birleşmiş Milletler Çocuk Hakları Sözleşmesi, Madde 1'deki tanımlamaya göre 18 yaşından küçük herkes çocuk olarak kabul edilmektedir (Çocuk, bir kentin nüfusu içerisinde azımsanamayacak bir orana sahiptir (Birol, 2009, s. 10). Çocuk, bugün ve gelecek arasında bir köprü; yarının da yetişkinleridir (Alpan, 2015, s. 207). Bu sebeple birey olarak topluma katılma sürecinde, çocukluk dönemi oldukça önemlidir. Alpan'ın da aktarmalarına göre çocuk mekanlarında çevre psikolojisinin önemli olduğu ve çocukluk döneminde çocuk ile mekân arasında kurulan ilişkinin yetişkinlik döneminde de devam ettiği görülmektedir (Alpan, 2015, s. 204). Çevre psikolojisi, mekân düzenleyiciler ve sosyal psikologların etkileşimi sonucu ortaya çıkmıştır. Genel olarak insan bir çevrenin parçasıdır ve içinde bulunduğu fiziksel çevre aynı zamanda sosyal bir sistemdir. Bu sebeple herkes, sistem içerisindeki rolüne göre tepkide bulunur (Morval, 1985, s. 28). Sistemin en küçük ve temel parçasının çocuklar olduğu düşünülürse, onların gelişip sağlıklı birey olarak topluma katılmalarında ait oldukları çevrenin kurgulanmasının oldukça önemli olduğu karşımıza çkmaktadır. Nitekim, çocukluk döneminde içerisinde bulunduğu çevre çocuğun gelişimindeki en önemli faktörlerdendir.

Geçmişte çocuklar için en önemli dış mekân oyun alanlarından birisi sokaklar olarak görülmekteydi. Ancak hızlı kentleşme sonucu gelişen trafik akışıyla birlikte sokaklar çocuk oyun alanları olarak güvenirliliğini yitirmiştir (Etli ve Yamaçli, 2015, s. 230). Dolayısıyla çocuklara ayrılmış çocuk oyun alanlarının varlığı ve bu alanların tasarımı, özellikle trafik akışının yoğun olduğu kent merkezlerinde büyük önem taşır hale gelmiştir. Bu çerçevede bu çalışma 
kent merkezlerinde çocuklara ayrılmış oyun alanlarının tasarımına odaklanmakta ve bu alanları "Sağlıklı Kent" tasarım kriterleri bağlamında irdelemeyi amaçlamaktadır. Çalışma kapsamında Eskişehir kent merkezindeki yedi adet parktaki çocuk oyun alanları incelenmiştir Birçok farklı disiplini bünyesinde barındıran sağlıklı kent kavramı, yaşanabilir bir kent için olması gereken tüm içerikleri kapsamaktadır (Başaran, 2007, s. 207). Bu sebeple sağlıklı kent, kenti oluşturan toplumun her bireyinin kentle kurduğu ilişkinin de sağlıklı olması koşulunu ortaya koyar. Dolayısıyla ilk olarak toplumun geleceğini oluşturan kentin en küçük üyeleri çocukların da kentle kurduğu ilişki büyük önem taşımaktadır. Bu doğrultuda çocukların kullanacağı mekanların, sağlıklı kent olma koşulunu içeren tasarım kriterleri doğrultusunda oluşturulmasına öncelik verilmelidir. Çocuğun fiziksel ve ruhsal gelişimindeki en önemli etkenlerden biri oyundur. Özellikle kentte gündelik hayatın içerisinde yer alan açık hava oyun alanları, çocuğun sosyal gelişimi için vazgeçilmez kent parçalarıdır. Bu kapsamda bu çalışma, kentlerde yaşayan çocuklar için oluşturulan çocuk oyun alanlarının sağlıklı kent tasarım kriterlerine uygunluğunun saptanması açısından önem taşımaktadır. Çalışma kapsamında öncelikle sağlıklı kent kavramı ve çocuk arasındaki ilişkiden bahsedilmiştir. Devamında ise, çocuk oyun alanı olan kent içerisindeki çocuk parklarının incelenmesindeki kriterler verilmiştir. Bu inceleme yazın taramasında var olan çocuk oyun alanlarının tasarlanmasındaki kriterlere göre (Friedberg, 1982; Uysal, 2013, s. 1-3) ve oyun alanı kategorilerine göre (Tandoğan, 2014, s. 3031) yapılmıştır. Ardından, çalışmanın bulguları doğrultusunda mevcut çocuk oyun alanlarındaki eksikliklerin giderilmesi ve bu alanların yeniden düzenlenmesine yönelik önerilerde bulunulmuştur.

\section{Yöntem}

Yapılan çalışma, toplum içerisinde var olan bir durumu incelediği için bir nitel araştırmadır. Amacına göre değerlendirme çalışması; yöntemine göre ise saha araştırması olarak ele alınabilir. Yapıldığı çevreye göre bir alan araştırmasıdır. Çalışma kapsamında yazın taraması (belgesel kaynak taraması), haritalandırma, yerinde tespitler ve gözlemlerden yararlanılmıştır. Çalışma metodolojisi Şekil 1'de grafiksel olarak ifade edilmiştir

Sağlıklı kent, yaşanabilir bir kent olarak kullanıcılarının ihtiyaçlarına cevap vermelidir. Bu bağlamda kentsel tasarıma yapılan müdahaleler kentin kullanıc1larının yaşam kalitesini etkilemektedir. Dolayısıyla kent ve kullanıcısı arasındaki ilişkiyi bilerek tasarımlar geliştirmek önemlidir. Sağlıklı kentler bağlamında kentsel tasarımı etkileyen; hava kirliliği, gürültü, doğal alanlar, sıcaklık ve fiziksel 
aktivite olmak üzere beş kriter öne çıkmaktadır (ISGlobal, 2018). Sağlıklı kentler bağlaminda çevre kalitesinin ölçülmesi makro boyut ve mikro boyutta gerçekleşmektedir. Makro boyuttaki analiz niceliksel içerikli olup kent içerisindeki yoğunluk ve çeşitlilik konularını ele alırken mikro boyuttaki analiz niteliksel içerikli olup kullanışlllık, emniyet, konfor ve estetik değerlerini analiz eder (Rebecchi, ve diğerleri, 2019, s. 7). Sağlıklı kentler için fiziksel aktivite kriteri bağlamında çocuk oyun alanları irdelenmiştir. Bu irdeleme, oyun alanlarının tasarım kriterlere göre ve oyun alanı kategorilerine göre analizler üzerinden gerçekleştirilmiştir. Bu kriterler yazın taramasında yer alan, çocuk oyun alanlarının tasarlanmasındaki kriterlere göre (Friedberg, 1982; Uysal, 2013, s. 1-3) ve oyun alanı kategorilerine göre (Tandoğan, 2014, s. 30-31) yapılmıştır.

Çalışma sonucunda, yapılan tespitler doğrultusunda çocuk ve kent ilişkisi bağlamında Eskişehir kent merkezinin sağlıklı kent kriterlerine uyabilmesi için önerilerde bulunulmuştur. Çalışma kapsamında Şekil 2'de ifade edilen kent merkezini oluşturan bölge incelenmiştir.

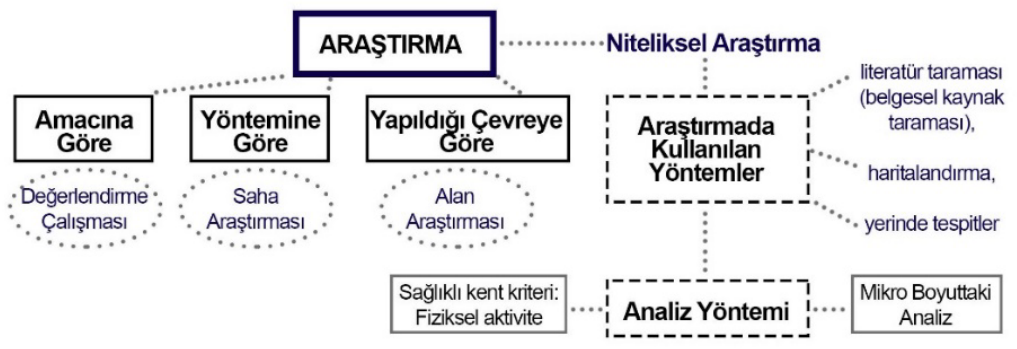

Şekil 1. Çalışma metodolojisi (Şekil yazarlar tarafından oluşturulmuştur)

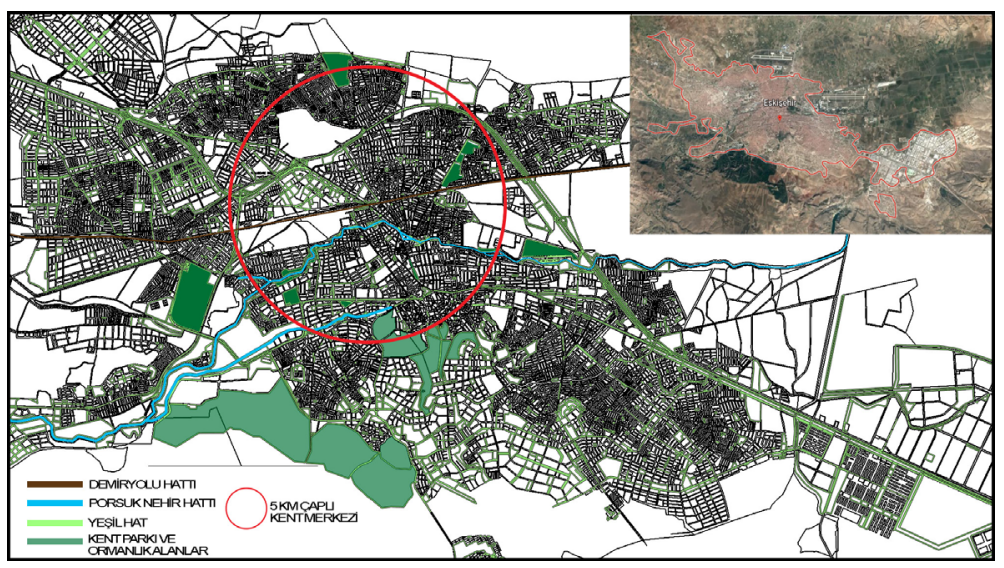

Şekil 2. Çalışma Alanı, Eskişehir Kent Merkezi (Kaynak: Atıcı 2020, Şekil yazarlar tarafindan oluşturulmuştur; Google Earth, 2021) 
UNICEF tarafından 18 yaşından küçük herkes çocuk olarak kabul edilmektedir. Buna karşın çocuk oyun alanlarının yoğun olarak 1-14 yaş arası çocuklar tarafından yoğun olarak kullanıldığı belirtilmiştir (Ünal, 2009, s. 99100). Bu sebeple Eskişehir 2017 yılı istatistiklerinde 14 yaşa kadar olan çocukların verileri incelenmiştir. Bu doğrultuda Eskişehir merkezinde 0-14 yaş arası toplam 138,06 (Odunpazarı: 75,625 çocuk, toplam nüfus 399,451+ Tepebaşı: 62,435 çocuk, toplam nüfus 353,179) çocuk bulunmaktadır (Ergen ve Çelik, 2018, s. 43). İstatistik verileri incelendiğinde Odunpazarı'nın yaklaşık yüzde 20'sini, Tepebaşı' nın ise yaklaşık yüzde 18'ini çocuklar oluşturmaktadır. Tablo 4'te de belirtildiği üzere, 2 Eylül 1999 tarih ve 23804 sayılı Resmî Gazete'de yayımlanan imar kanuna göre, $10 \mathrm{~m}^{2}$ kişi'lik öneri yeşil alan için kişi başına yaklaşık $2.114 \mathrm{~m}^{2}$ çocuk oyun alanına ihtiyaç duyulmaktadır (Resmî Gazete, 1999). Bu bilgilere göre, istatistik değerleri Eskişehir merkezindeki çocuk nüfusuna karşılık gerekli çocuk oyun alanlarının bulunmadığını göstermektedir. Tamamlanan analizler bulgular bölümünde yer almaktadir.

\section{Sağlıklı Kent Kavramı ve Çocuk}

Sağlıklı kent; kirlilik, suç, stres ve işsizliğin minimuma indirildiği, tüm insanların yaşlarına, cinsiyetine, rrkına, fiziksel ve sosyal durumlarına bakılmaks1zın ihtiyaçların karşıladığı, sağlıklı yaşam sürdüğü yerlerdir (Barton ve Tsorou, 2005, s. 167). Birçok farklı disiplini bünyesinde barındıran sağlıklı kent kavramı, yaşanabilir bir kent için olması gereken tüm içerikleri kapsamaktadır. Yaşanabilir bir kent ise daha sağlıklı yaşamayı amaç edinmiş, sağlıklı, huzurlu ve yaşanabilir kent olma yolunda kararlığını sürdüren kenttir (Başaran, 2007, s. 207). Kentlerin yaşanabilirliği kentsel çevreden etkilenmektedir. Bu etki, kentin aktif yaşam tarzıyla toplumu aktif hala getirmesi ya da cesaretini kırması şeklinde ifade edilmektedir (Rebecchi, ve diğerleri, 2019, s. 14). Dolayısıyla insan davranışları üzerinde etkili olan kentin, insan sağlığında da etkili olması kaçınılmaz bir gerçektir. Aktif kamusal yaşam daha sağlıklı ve sosyal açıdan sürdürülebilir bir kent kavramını ortaya koyar. Aktif yaşamın başarılı olması ise kullanıcısının ihtiyaçlarına cevap vermesine bağlıdır (Bishop ve Marshall, 2017, s. 63,67). Bu sebeple sağlıklı kentin yaşanılabilir kent olduğu ve bu bağlamda kullanıcısıyla temasa geçtiği söylenebilir. Kentlerde ortak toplumsal faaliyetlere imkân veren alanlar kamusal alanlardır. Bu alanların kullanıcıları; fiziksel ve sosyal yönden farklılıklar taşımaktadır. Bu ifadelerden yola çıarak, yaşanabilir sağlıklı kentlerin, bütün kullanıcılarının ihti- 
yaçlarına cevap vermesi beklenmektedir. Kentin en küçük kullanıcıları çocuklardır. Bu sebeple sağlıklı bir kent olma yolunda temelde çocukların ihtiyaçlarına cevap vermek, sağlıklı bir kentin sürdürülebilirliğinde önem taşımaktadır. Çocuğun dünyayla olan ilişkisi ev ve kentte kurulmaktadır (Seçmen, 2016, s. 45). Çocuklara nasıl davranılırsa onların gelişiminin de o yönde etkileneceği söylenebilir. Bu sebeple çocuklara yetersiz ve küçük muamelesi yapıldığında gelişimleri olumsuz etkilenecektir. Ancak çocukların da toplumda bir birey oldukları kabul edilip bu doğrultuda davranıldığında çocukların davranışları da olumlu şekilde gelişecektir. Bu gelişim onların daha sağlıklı bir birey olarak topluma katılmalarını da etkileyecektir.

Günümüzde endüstrileşme ve kontrolsüz kentleşme sonucunda araç trafiği yoğunlaştığı için sokaklar oyun alanı olarak çocuklar için tehlikeli bir hal almıştır. Buna ek olarak kentlerde çocuklar için yeterli oyun alanları da bulunmamaktadır. Bu olumsuzluklar doğrultusunda çevre ilişkileri hızla azalan çocuklar içlerine dönerek yalnızlaşmaktadırlar. Çocukların içlerine dönmesinin, kendi yaş gruplarındaki çocuklarla iletişim kurup oyun oynayabileceği ve paylaşımda bulunacağı mekanların az olmasından kaynaklandığı söylenmektedir (Ermiyagil ve Gürçınar, 2015, 19). Çocukluk döneminde hayatı çocuk parklarında öğrenmeye başlayan çocuklar için buralardaki aktiviteler ve paylaşımlar çok önemlidir. Ayrıca çok katlı apartmanlar içindeki yaşam, çocukların dış mekandaki oynama hakkına da engel olmaktadır. Sokakta oynarken çocuğun aidiyet bilincini geliştirebileceği kente ait; ağaç dalları, ağacın kovuğu, duvar önü, merdiven etrafı, dere kenarı gibi birçok yer ile çocuk karşılaşamayarak bu mekanlara özgü deneyim edinememektedir (Özerk, 2014, s.15). Bu sebeple çocukların kentle olan teması oldukça sınırlı kalmaktadır. Sokak, kentsel dokuda yer değiştirmeyen; kente ve kentliye hareket sağlayan ögelerdir (Üstün ve Özkan, 2016, s.64). Dolayısıyla sokakların insanın çevresindeki değişmeyen fiziki dokusunu oluşturduğu söylenebilir. Son zamanlara kadar, kentin en küçük sakinleri olan çocukların, sokaklarda oyun oynadığı ve yaşamı öğrendiği söylenebilirdi. Ancak günümüz koşullarının bu duruma pek de imkân vermediği görülmüş̧ür. Bu sebeple kent içerisinde çocuklara ayrılan çocuk oyun alanlarını, çocuk gelişimi için büyük önem arz etmektedir. Bu önem dahilinde çocuk oyun alanlarının tasarlanmasında belirli bazı kriterler bulunmaktadır. Churchman'ın ifadesiyle kent içerisindeki oyun alanlarının sahip olması gereken nitelikler tablo haline getirilerek Tablo 1'de ifade edilmiştir (Churchman, 2003, s.108): 
Tablo 1. Oyun Alanlarının Sahip Olması Gereken Nitelikler (Kaynak: Churchman, 2003, s. 108)

\begin{tabular}{ll}
\hline Eve yakınlık & $\begin{array}{l}\text { Doğal alanların yanı sıra farklı zemin } \\
\text { kaplamalarının bulunması }\end{array}$ \\
\hline Çocuk yürüme mesafesinde olma & $\begin{array}{l}\text { Çocuk eylemlerini kısıtlamama ve doğal } \\
\text { unsurların varlığı }\end{array}$ \\
\hline Fiziksel ve görsel erişilebilirlik & Trafik ve yetişkinler açısından güvenli \\
\hline Kentsel aktivitelere yakınlık & İklim şartları konforlu \\
\hline Çocuk aktiviteleri için yeterli açık alan & $\begin{array}{l}\text { Oturma alanlarının varlığı ve denetleyen } \\
\text { yetişkinlerin evlerine yakınlık }\end{array}$ \\
\hline $\begin{array}{l}\text { Farklı oyun türlerinin ve farklı yaş gruplarnın } \\
\text { bulunması }\end{array}$ & \\
\hline
\end{tabular}

Kentsel yaşam kalitesi; toplumun yaşam kalitesi ve çevre kalitesinin karşılıklı etkileşiminde gerçekleşmektedir (Emür ve Onsekiz, 2007, s.367). Bu sebeple insan sağlığıyla birlikte çevrenin de sağlıklı olması hem toplum yaşamını hem de kenti sağlıklı kılmaya başlayacaktır. Kenti, yaşayan canlı bir organizma olarak ele aldığımızda kenti oluşturan her canlı parçanın bu bağlamda sağlıklı olması, kenti daha sağlıklı duruma getireceği ileri sürülebilir.

\section{Kentsel Mekânda Çocuk Oyun Alanları ve Özellikleri}

Kontrolsüz trafiğin yoğunlaşması, sosyal korkular, şiddet, kamusal alan ve tesislerin yetersizliği, şehirleri çocuklar ve gençler için düşmanca bir yer haline getirmiştir (Bartlett, 2002, s. 3). Ancak sağlıklı bir kent içerisinde kenti oluşturan tüm bireylerin toplum içerisinde rahatlı̆̆ söz konusudur. Bu bağlamda çocukların da her yetişkin gibi topluluğa aktif katilma hakknna sahip olduğu söylenmektedir (Gökmen ve Taşç, 2016, s.470). Bireylerin çocukluk dönemindeki sosyal ve duygusal gelişimleri ilerleyen yaşlarda da bu duyguların temelini oluşturmaktadır. Harvey'in şehir hakkı açıklamasında dediği (Harvey, 2015, s. 44), bireylerin şehirden faydalanma hakkı ve ihtiyaçları doğrultusunda değiştirebilmesi kentin en küçük bireyleri olan çocuklar için de geçerlidir. Oyun eylemi çocuklar için bir hak olup onların gelişmesini destekleyen bir ihtiyaç gibi davranmaktadır (Uz ve Çabuk, 2006, s.1-2). Çocuklar oyun sayesinde yardımlaşma, paylaşma gibi yetiler kazanarak sosyalleşmeye başlamaktadır (Koçan, 2012, s.315).

Çocuğun temel bir insan hakkı olarak oynama hakkını korumak ve teşvik etmek amaciyla 1961'de "İnternational Play Association, IPA" adıyla bir sivil toplum örgütü kurulmuştur. IPA'nın Türkiye'nin de arasında bulunduğu 50'ye yakın ülkeden üyesi bulunmaktadır (IPA, 2020). Her çocuğun en doğal hakkı ve eğitimlerinin temeli olan oyun, çocuklara birçok beceri ve deneyim kazandırmaktadır. Oyun da tüm etkinlikler gibi bir çevrede gerçekleşir. Çocuk oyun alanları sadece fiziksel değil aynı zamanda zihinsel gelişime de katkı sağlar (Gökmen, 2009, s. 48). Başka bir ifadeyle 
oyun, sadece boş vakit değerlendirmenin değil aynı zamanda hayatı öğrenmenin de bir yoludur (Şişman ve Özyavuz, 2010, s. 13). Eğitim ise sadece okullarla sınırlı kalmayıp okul dışında da devam eden bir etkinliktir. Çocuk oyun alanları da diğer birçok kurum (müze, kütüphane vb.) gibi eğitim sürecinde yer almaktadır.

Çocuk oyun alanları çocukların paylaşımda bulunduğu ortak alanlardır. Ortak alan; kahıc olmayan, her türlü dış etkiye açık toplumsal ilişki biçimi olup kentsel mekanlar gibi sürekli üretilmektedir (Harvey, 2015, s. 125,130). Bu sebeple çocuk oyun alanlarının dışarıya açık olup sürekli değişime uğradığı düşünülebilir. Oyun alanlanı, çocukların yeteneklerini keşfetmesi, kendisini tanıması, bedensel, psikolojik vb. birçok yönden gelişmesi için oldukça önemlidir. Buna ek olarak oyun alanlarını; 1-14 yaş arası çocukların yoğun olarak kullandığı rekreasyonel ihtiyaçlarının karşılandığı açık alanlar olduğu söylenebilir (Ünal, 2009, s. 99-100).

Oyun, engelli ya da engelleri olmayan tüm çocuklar için bir haktr. Engelli ya da engelsiz tüm çocuklar bir arada oynadığında birbirlerinin farklılıklarını ve benzerliklerini göreceklerdir. Bu süreç yetişkin olup toplumu anlamlandırma için bir adımdır (Gökmen, 2009, s. 50). Ayrıca tüm çocukların eğitiminde olduğu gibi, zihinsel engelli bireylerin eğitiminde de onların ileride başkalarına bağımlı olmadan kendi kendilerine yetecek hale gelmelerini sağlamak temel hedeftir (Öztürk, 2010, s. 139). Bu sebeple yapılan tasarımları, her türden bireyin kullanımına açk olmasına dikkat edilmelidir.

20Kasım 1989'da kabul edilenUNICEF Çocuk Haklarına Dair Sözleşme 54 maddeden oluşmaktadır. Bu maddelerin 31. Maddesinde; “Taraf Devletler, çocuğun kültürel ve sanatsal yaşama tam olarak katilma hakkını saygı duyarak tanırlar ve özendirirler ve çocuklar için, boşzamanı değerlendirmeye, dinlenmeye, sanata ve kültüre ilişkin (etkinlikler) konusunda uygun ve eşit firsatların sağlanmasın teşvik ederler" ifadesi yer almaktadır (Unicef, 1989).

Çocuk oyun alanları dört kategori halinde ele alınabilir. Bu durum Tablo 2'de ifade edilmiştir.

Tablo 2. Oyun Alanları Kategorileri (Kaynak: Tandoğan, 2014, s. 30-31)

1. Geleneksel oyun alanları Salıncak, tahterevalli vb. aletlerin bulunduğu parklardır. Kas gücünün kullanarak aktivitede bulunurlar. Yaratıcılığa katkıda bulunmaz. Bu sebeple oyun amaçlı değil aktivite amaçlıdır.

2. Çağdaş çocuk oyun alanlan Geleneksel oyunun gelişmiş hali olup; alışlmamış form ve renkler karşımıza çkar. Maliyeti yükssek olduğundan çok sık görülmez.

3. Macera oyun alanları Gerçek araç ve gereçle kendi oyunlarını tasarlamasıdır. Kendilerini keşfetmelerine olanak tanır.

4. Özel öğrenme alanlanı

Deneyimleme imkânlarını uygulamalar sunmaktadır. Biliş zenginleştirmeyi hedefler. 
Tablo 2'de verilen oyun alanlarından, günümüz kentlerinde karşımıza en çok çıkan örneğin geleneksel oyun alanları olduğu söylenebilir. Günümüz imkanları düşünüldügü̈nde çocukların vakit geçirebileceği, eğlenebileceği birçok seçenek bulunmaktadır. Çocuklar meraklıdırlar. Bu sebeple çocuklar için ilgi çekici yerlerin onların düşündüklerini oluşturmalarına firsat sunan yerler olduğu söylenebilir. Oyun donatılarında bunun var olduğunu düşünmek yanlıştır; ancak çocuklara bunları değiştirme imkânı sunmak oldukça önemlidir. Bu bağlamda kullanışsız donatılar kaldırılıp yeni bir kurgu oluşturulabilir. Bu alan iki avantaj sunar (Gökmen, 2008, s.52):

- Geleneksel oyun alanlarından daha ucuzdur.

- Yetişkinler için karmaşık görünse de çocuklar tarafından daha çok tercih edilir.

Çocukların kent içerisindeki oyun haklarını istedikleri gibi kullanabilmeleri için; çocuk oyun parkının, parkı oluşturan malzemelerinin özelliklerinin, parka gelen çocukların birbirleriyle ve yetişkinlerle olan etkileşimlerinin iyi bilinmesi gerekmektedir (Ramazan ve Özdemir, 2015, s. 1563). Çocuğa sadece oyuncak vermek, onların gelişimi için yeterli değildir. Geleneksel oyun alanlarındaki durum da genellikle oyuncaklardan ibarettir. Bu oyun alanları sadece fiziksel aktiviteye katkı sağlamaktadır. Çocuğun diğer yönden gelişimine katkı sağlamaz, sadece vakit geçirmesini sağlar. Bu sebeple tüm koşulların düşünülerek tasarıma entegre edilmesi daha doğru olacaktır. Bu şekilde mekânın tasarımını sağlıklı bir şekilde meydana gelecektir.

Çocuklar bilgi edinme yöntemi olarak; oyun, gözlem ve duygularından yararlanırlar. Bu sebeple iç mekân ve diş mekandaki farklı çevreler, malzemeler ve dokular onun duyusal yeteneklerini artıracaktır. Çocukların duyu bilincini harekete geçiren bu çeşitlilikler fiziksel gelişim oluşturmasa da duyusal algılamalarını geliştirerek hayata adapte olmasına destek olur (Çanakçığlu, 2012, s. 2,3). Oyun alanlarındaki çalılar, su, kayalar ve kum gibi doğal unsurlar, bu özelliklere sahip olmayan oyun alanlarına kıyasla daha fazla oyun firsatı ve güneş ve rüzgâr gibi orta çevre koşullarını sunabilir (Herrington ve Brussoni, 2015, s.481). Dolayısıyla, çocuklar için tasarlanan mekanlarda, doğa elemanlarının varlığının onların sağlıklı gelişimi için kaçınılmaz olduğu söylenebilir. Oyun alanlarında bulunan doğal unsurların çocukları oyuna teşvik etmesindeki önemli etkenlerin başında çocukların merak duygusu gelmektedir. Oyun alanında var olan farklılıklar, çocuğu oyuna teşvik edecektir. 
Muhacir ve Özalp'ın yaptığı çalışma sonucunda, yeterli ve kaliteli bir çocuk alanının oluşturulmasında planlama ve tasarım kriterleri çerçevesinde tespitler yapılmıştır. Bu tespitler Tablo 3'te ifade edilmiştir.

Tablo 3. Yeterli ve Kaliteli Bir Çocuk Alanının Oluşturulmasında Planlama ve Tasarım Kriterleri (Kaynak: Muhacir ve Özalp, 2016, s. 229)

\begin{tabular}{|c|c|}
\hline - Planlama & - Tasarım \\
\hline - Güvenlik & - Oyun elemanlarının malzemesi \\
\hline - Erişilebilirlik & - Bitki varlığ \\
\hline - Engelli erişimi & - Oyun elemanlarının çeșidi \\
\hline
\end{tabular}

Tablo3'te de görüldüğü üzere, çocuk oyun alanında oyun malzemelerinin dışında doğal peyzaj unsurlarının bulunması gerektiği belirtilmiştir. Fiziksel planlama ve tasarım sürecinin birbirinden farklı olduğu; tasarımcının mekânı algılayışı ve çocuğun bakış açısının tasarımı etkileyeceği belirtilmektedir. Bu sebeple çocuk oyun alanlarının, kent içerisindeki boşlukların birkaç donatının rast gele düzenlemesi ile oluşturulmaması gerektiği ifade edilmiştir $(\mathrm{Mu}-$ hacir ve Özalp, 2016, s. 229). Çocuk oyun alanlarının içerisinde bulunduğu alanların başında parklar gelmektedir.

Parklar, kent içerisinde yeşil alan oluşturmasıyla yapılı alan ve doğal çevre arasında dengeli arazi kullanımı sağlamaktadır. Farklı insanların karşılaşmasına, tanışmasına yani iletişim kurmasına firsat tanıyan kültürel odaklı bir merkez olarak toplumda rolü oldukça önemlidir (Emür ve Onsekiz, 2007, s. 371). Parklar, kullanım amacına ve içeriğine göre çeşitlilik göstermektedir. Parkların bir çeşidi de toplumun küçük bireyleri olan çocukların kullanımına yönelik olan çocuk parklarıdır. Çocuk parkları, çocukların oyun oynamak, fiziksel ve sosyal aktivitelerde bulunmak gibi temel haklarını kullandıkları yer olan, oyun alanlarından meydana gelmektedir.

Çocuk oyun alanları; kentteki açık yeşil alanların önemli bir parçasını oluşturmaktadır (Şişman ve Özyavuz, 2010, s. 13). İmar Planı Yapılması ve Değişikliklerine Ait Esaslara Dair Yönetmelik'te; çocuk bahçesi, oyun alanları ve parklar aktif yeşil alan olarak değerlendirilmiştir. Bu değerlendirilme içinde kişi başına 10 metre kare; belediye ve mücavir alanlar dişındaysa kişi başı 14 metre kare olarak düşünülerek planlanması gerektiği ifade edilmiştir (Resmî Gazete, 1999). Çocuk oyun alanları kent yeşil sistemi içerisinde önemli bir yer tutmakta ve bu alanlar ülkeden ülkeye değişmektedir. Türkiye'deki çocuk oyun alanlarının olması gereken ideal büyüklükleri elde edilen bilgiler doğrultusunda Tablo 4 'te ifade edilmiştir. 
Tablo 4. Ülkelere göre değişen çocuk alanı büyüklük öneriler (Kaynak: Yılmaz ve Bulut, 2003 ve Aksoy, 2011, s. 85)

\begin{tabular}{|c|c|c|}
\hline Ülke & Oyun alanı kapsamı & Birey sayısı \\
\hline \multirow[t]{3}{*}{$\begin{array}{l}\text { Türkiye (çocuk bahçesi) } \\
\text { öneriler mevcut }\end{array}$} & Çocuk bahçesi & $\begin{array}{l}\text { - } 1000 \mathrm{~m}^{2} \text { den az olmamalı } \\
\text { - } \quad \text { Her çocuk için } 6.5 \mathrm{~m}^{2} \text { ayrlarak, en küçük çocuk } \\
\text { bahçesinin } 250 \mathrm{~m}^{2} \text { den küçük olmamalı } \\
\text { - } \quad \text { Yerleşim alanı büyüdükçe } 250-1000 \mathrm{~m}^{2} \mathrm{ye} \\
\text { kadar genişlemeli }\end{array}$ \\
\hline & $\begin{array}{l}\text { 2 Eylül } 1999 \text { tarih ve } \\
\text { 23804 saylı Resmî }\end{array}$ & $\begin{array}{l}\text { - } \quad 10 \mathrm{~m}^{2} \text { kişi'lik öneri yeşil alan için kişi başına } \\
\text { yaklaşı } 2.114 \mathrm{~m}^{2} \text { çocuk oyun alanı }\end{array}$ \\
\hline & $\begin{array}{l}\text { Gazete'de yayımlanan } \\
\text { imarkanunu }\end{array}$ & $\begin{array}{l}\text { - } 5000 \text { nüfuslu ilköğretim ünitesi düzeyinde } 1,5 \\
\mathrm{~m}^{2} / \text { kişi yeşil alan (oyun+çocuk bahçesi) } \\
15000 \text { nüfuslu mahalle ünitesi düzeyinde } 4 \\
\text { - } \mathrm{m}^{2} / \text { kişi yeşil alan }\left(2 \mathrm{~m}^{2} \text { mahalle parkı, } 2 \mathrm{~m}^{2} \text { spor }\right. \\
\text { alanı) } \\
\text { - } 45000 \text { nüfuslu kent ünitesi düzeyinde } 4,5 \\
\mathrm{~m} 2 / \text { kişi yeşil alan ( } 3,5 \mathrm{~m}^{2} \text { park, } 1 \mathrm{~m}^{2} \text { stadyum) }\end{array}$ \\
\hline
\end{tabular}

Oyun parkları çocukların enerjisini atacağı ve yaramazlık yapacakları bir yerden daha fazlasıdır. Burası çocukların kalıcı ilişkiler kuracağı bir yer olmalıdır. Çünkü, ortalama bir bireyin isteklerini tanımlayan ve karakterini oluşturan en önemli yer oyun grubudur. Bu sebeple oyun alanlarl; okul, dini alanlar ve yerel kurumlar kadar insan karakterini oluşturan yerler olmalıdır (Park, 2018, s. 157). Daha kısa bir ifadeyle oyun alanı, çocukların oynadığı her yerdir. Kentleşme sürecinde çocukların oyun oynamaları için düzenlenmiş güvenli alanlara ihtiyaç artmıştır. Her ne kadar değişimler yaşansa da çocuk parklarının tasarlanmasında temel kriterler bulunmaktadır. Bu kriterler Tablo 5'te ifade edilmiştir (Friedberg, 1982; Uysal, 2013, s. 1-3):

Tablo 5. Çocuk Parklarının Temel Tasarım Kriterleri (Kaynak: Friedberg, 1982; Uysal, 2013, s. 1-3)

\begin{tabular}{ll}
\hline Erişilebilirlik & $\begin{array}{l}5 \text { yaşındaki bir çocuk evinden konut birimindeki parka 2-3 } \\
\text { dakikada; mahalle parkına ise } 10 \text { dakikada ulaşabilmelidir. }\end{array}$ \\
\hline Güvenlik & $\begin{array}{l}\text { Malzeme ve tasarımlar standartlara uygun olmalıdır. Türkiye'de } \\
\text { de oyun alanları standardı, Türk Standartları Enstitüsü } \\
\text { tarafından belirlenmiştir; TSE EN } 1176 \text { (Uysal, 2013, s. 2). }\end{array}$ \\
\hline $\begin{array}{l}\text { Çeşitlilik ve } \\
\text { çekicilik }\end{array}$ & Farklı aktivitelere imkân sağlamalıdır. \\
\hline Kontrol & $\begin{array}{l}\text { Ebeveynler çocuklarını oturduğu yerden görebilmelidir. Parkın } \\
\text { bir sınırı olmalı ve çevrilmelidir. }\end{array}$ \\
\hline
\end{tabular}




\begin{tabular}{ll}
\hline Karma kullanım & $\begin{array}{l}\text { Farklı yaş gruplarının bir arada bulunmasına imkân } \\
\text { sağlamalıdır. }\end{array}$ \\
\hline Doğru malzeme & $\begin{array}{l}\text { Sentetik malzemeler yerine ahşap ya da benzeri doğal } \\
\text { malzemeler tercih edilmelidir. }\end{array}$ \\
\hline Sosyalleştirici & Çocukların ve büyüklerinin de birbiriyle temasını sağlamalıdır. \\
\hline Peyzaj & $\begin{array}{l}\text { Kentlerin yeşil alanları içerisinde yürüme ve bisiklet yollarıyla } \\
\text { desteklenerek tasarlanmalıdır. Mekânsal ve işlev olarak esnek } \\
\text { olmalıdır. }\end{array}$ \\
\hline Kullanıcı talepleri & Kültürel farklılıklar ve alışkanlıklar, tasarıma dahil edilmelidir. \\
\hline
\end{tabular}

Tasarımda dikkat edilmesi gereken bir diğer husus ise yaş grubuna göre oyun alanlarının nasıl olması gerektiğidir (Ermiyagil ve Gürçınar, 2015, s. 20). Tablo 5'e ek olarak; oyun araçların fiziksel gelişime yardımcı olduğu bu sebeple de yaş gruplarına göre farklılık göstermesi gerektiği söylenebilir. 2-6 yaş arası okul öncesi olarak nitelendirilebilecek çocuklar daha küçük yapılı oldukları için emekleme mekanlarına, uygun boyutlarda kulplara ve parmaklıklara ihtiyaç duymaktadır. Emekleme alanları, kum-su alanları, alçak kaydıraklar gibi küçük ölçekli oyun araçları bu yaş grubu için idealdir. Daha büyük yaş gurubundaki çocukların fiziksel gelişimi için ise hareket barları, tırmanma üniteleri, açık ve kapalı mekanlardan oluşan imitasyon oyun alanları, kaydıraklar gibi oyun araçları idealdir (PEYZAX, 2011).

Yapılan çalışma kapsamında da çocukların sıklıkla vakit geçirdiği çocuk oyun alanlarının tasarımsal bağlamda analizi yapılmıştır. Bu şekilde olumlu ve olumsuz yönleri saptanarak geleceğe dönük çocuk oyun alanları için öneriler ortaya konulmuş olacaktır.

\section{Eskişehir Kent Merkezinde, Çocuk Parklarındaki Oyun Alanlarının Analizi}

Eskişehir' in kent merkezindeki 2006 yılına ait mevcut çocuk oyun alanları Şekil 3 'te ifade edilmiştir. Kent merkezi alan sınırları demiryolunun içinden geçtiği 5 km'lik alan içerisinde sınırlandırılmıştır. Bu sınırın içindeki parkların tespit edilmesi ve 2006 yılındaki haliyle günümüzdeki mevcut durumun karşılaştırılması ise Şekil 4'te görülmektedir. 


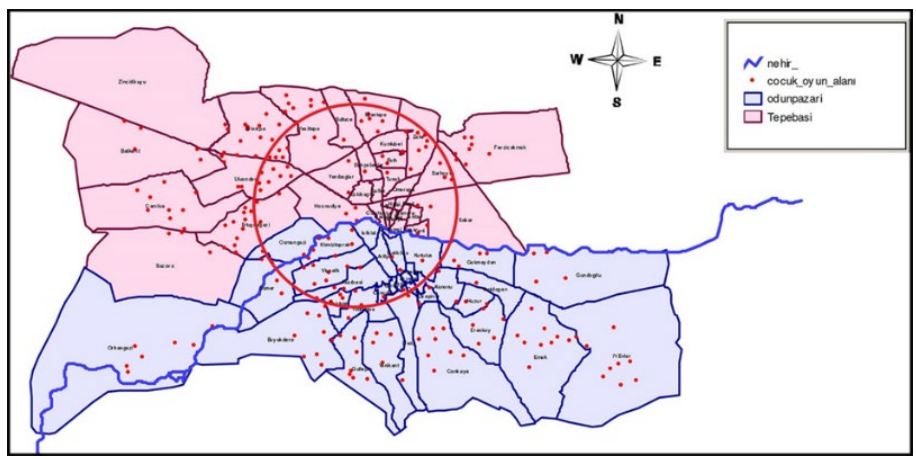

Şekil 3. Eskişehir Kent Merkezi Çocuk Oyun Alanları, 2006 (Kaynak: Uz ve Çabuk, 2006, s. 5)

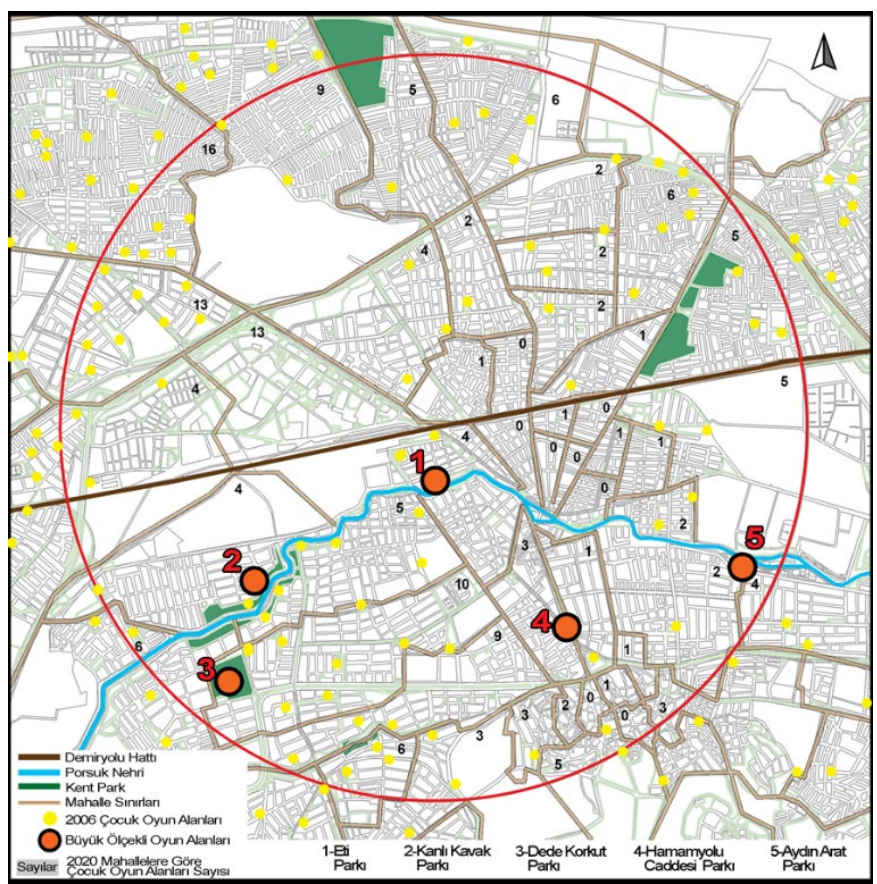

Şekil 4. Eskişehir Kent Merkezi Çocuk Oyun Alanları, 2006-2020 Değişimi (Şekil yazarlar tarafindan oluşturulmuştur)

Şekil 4'e göre kent merkezinde 5 adet büyük ölçekli park bulunmaktadır. Bunlar; Eti Parkı, Dedekorkut Parkı, Kanlı Kavak Parkı, Hamamyolu Caddesi Parkı ve Aydın Arat Parkı'dır. Bu parklar çocuklar için, geleneksel oyun parklarına göre daha dikkat çekicidir. Çünkü çocuklar için farklllıklar dikkat çekici olmaktadır. Çocuk oyun alanlarındaki çukurlar, tepeler, farklı renk ve malzemeler gibi çeşitlilikler çocuklarda heyecan uyandırmaktadır. İncelenen kent merkezinde böyle farklılıklara sahip Eti Parkı, Dedekorkut Parkı, Kanlı Kavak Parkı, 
Hamamyolu Caddesi Parkı (Hamamyolu Park ve Meydan düzenlemesindeki gerçekleşen Hamamyolu Caddesi'ndeki park projesini ifade etmek için kullanılmıştır. Yediler Parkı olarak da geçmektedir.) ve Aydın Arat Parkı görülmüştür. Diğer parklar, plastik malzemelerden oluşmuş küçük ölçekli geleneksel oyun parklarıdır.

Eti Parkı'na ait fotoğraflar Şekil 5'te ifade edilmiştir. Eti Parkı sahip olduğu doğal peyzajı ve Porsuk Nehri etrafında konumlanmasıyla dikkat çekmektedir. Bu parkta çocuklara yönelik geleneksel oyun alanları bulunmaktadır.

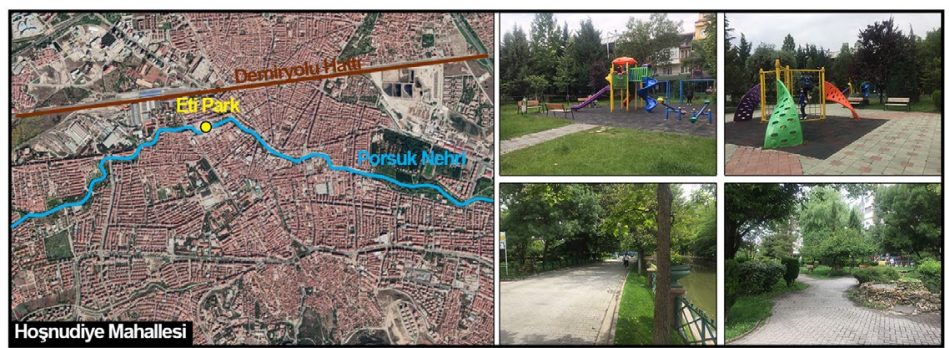

Şekil 5. Eti Parkı'na Ait Fotoğraflar (Kaynak: Atıc 2020, Şekildeki fotoğraflar yazarlar tarafından çekilmiştir; Google Earth, 2020)

Şekil 5'te gösterilen Eti Parkı, Tablo 5'te belirtilen çocuk parkları temel tasarım kriterlerinden doğru malzeme kriteri hariç diğer tasarım kriterlerini (erişilebilirlik, güvenlik, çeşitlilik ve çekicilik, kontrol, karma kullanım, sosyalleştirici, peyzaj, kullanıc talepleri) karşılamaktadır. Doğru malzeme için sentetik malzemeler yerine ahşap ya da benzeri doğal malzemeler tercih edilmelidir ancak Eti Parkı bu kriteri sağlayamamıştır.

Dede Korkut Parkı'na ait fotoğraflar Şekil 6' da ifade edilmiştir. Dede Korkut Parkı farklı oyun araçlarıyla çocukların ilgisini çekmektedir. Bu park sadece çocuklara değil birçok yaş grubuna hitap ederek teması artırmaktadır.

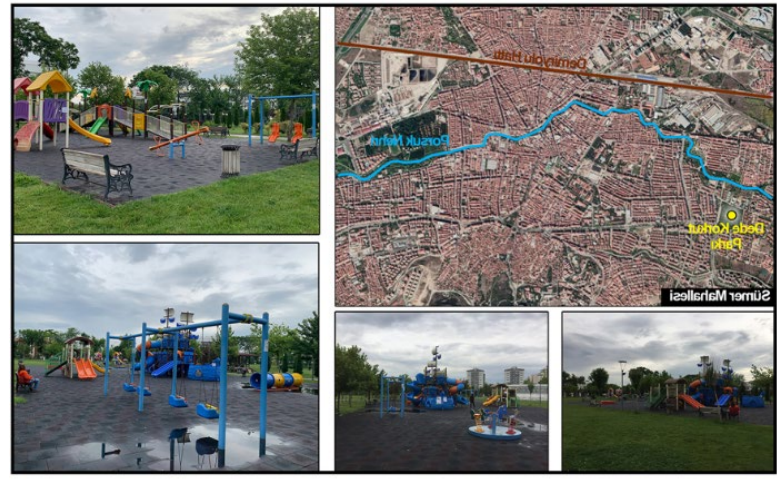

Şekil 6. Dede Korkut Parkı'na Ait Fotoğraflar (Kaynak: Atıcı 2020, Şekildeki fotoğraflar yazarlar tarafından çekilmiştir; Google Earth, 2020) 
Şekil 6.'da gösterilen Dede Korkut Parkı, Tablo 5'te belirtilen çocuk parkları temel tasarım kriterlerinden doğru malzeme kriteri hariç diğer tasarım kriterlerini (erişilebilirlik, güvenlik, çeşitlilik ve çekicilik, kontrol, karma kullanım, sosyalleştirici, peyzaj, kullanıcı talepleri) karşılamaktadır. Doğru malzeme için sentetik malzemeler yerine ahşap ya da benzeri doğal malzemeler tercih edilmelidir ancak Dede Korkut Parkı, Eti Parkı'nda olduğu gibi bu kriteri sağlayamamıştır.

Kanlı Kavak Parkı'na ait fotoğraflar ise Şekil 7'de ifade edilmiştir. Kanlı Kavak Parkı ise sahip olduğu doğal peyzajı ve Porsuk Nehri etrafında konumlanmasiyla dikkat çekmektedir. Bu parkta çocuklara yönelik sadece geleneksel oyun alanları bulunmaktadır.

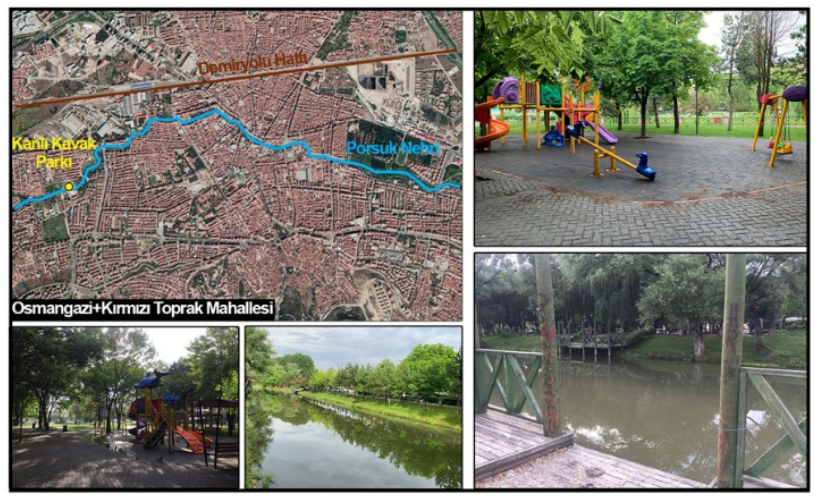

Şekil 7. Kanlıkavak Parkı'na Ait Fotoğraflar (Kaynak: Atıcı 2020, Şekildeki fotoğraflar yazarlar tarafından çekilmiştir; Google Earth, 2020)

Hamamyolu Caddesi Parkı'na ait fotoğraflar Şekil 8'de ifade edilmiştir. Hamamyolu Caddesi Parkı sahip olduğu yeşili, çukurları, bölmeleri, farklı zemin malzemeleri, renkleri ve oyuncakları ile çocuklara farklı bir oyun alanı kurgulamaktadır.

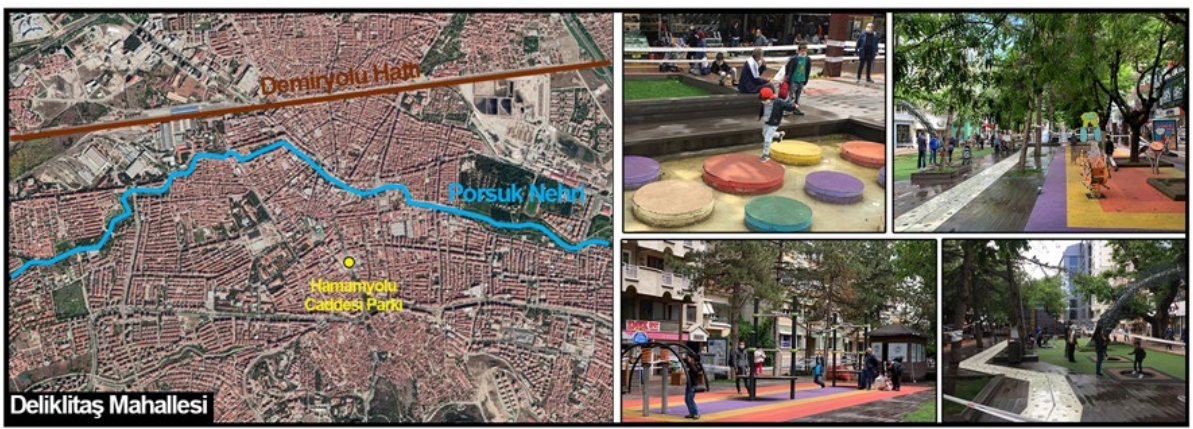

Şekil 8. Hamamyolu Caddesi Parkı'na Ait Fotoğraflar (Kaynak: Atıcı 2020, Şekildeki fotoğraflar yazarlar tarafından çekilmiştir; Google Earth, 2020) 
Şekil 8'de görüldüğ̈ü üzere Hamamyolu Caddesi Parkı'nda çocuklar için farklı aktivite alanları bulunmaktadır. Salıncak ve kaydırak gibi park donatılarının yanı sıra tepeler, çukurlar ve macera parkurlarının bulunması çocuklarda heyecan uyandırmaktadır. Çocuklar dışında, genç ve yetişkinler bir arada bulunabilmektedir. Toplumun diğer bireyleriyle bir arada bulunma imkânı vermesi, çocukların kente katılmalarında ve kentli ile temas kurmalarında etkili olmaktadır. Hamamyolu Caddesi Parkı'nın farklı zemin malzemeleri ve parktaki çocuk oyun alanlarının zemin malzemelerinde de farkl1lıklar bulunmaktadır. Yeşil alanlar ve oyun alanları içerisinde su ile temas sağlanmaktadır. Dolayısıyla, Tablo 5'te belirtilen çocuk parkları temel tasarım kriterlerini (erişilebilirlik, güvenlik, çeşitlilik ve çekicilik, kontrol, karma kullanım, doğru malzeme, sosyalleştirici, peyzaj, kullanıcı talepleri) karşılamaktadır. Ancak, Eti Parkı ve Dede Korkut Parkı'ndaki gibi çocuk parkındaki oyuncaklarda plastik kullanımı mevcuttur. Bu sebeple doğru malzeme kriterini tam anlamıyla karşılayamamıştır.

Aydın Arat Parkı'na ait fotoğraflar ise Şekil 9'da ifade edilmiştir. Porsuk Nehri etrafında konumlanmasıyla suyla görsel ve işitsel temas sağlamaktadir.



Şekil 9. Aydın Arat Parkı'na Ait Fotoğraflar (Kaynak: Atıcı 2020, Şekildeki fotoğraflar yazarlar tarafından çekilmiştir; Google Earth, 2020)

Şekil 9'da Aydın Arat Parkı'nda özellikle yeşilin etkili olduğu görülmektedir. Ancak Hamamyolu'nda olduğu kadar çocuklara oyun oynama konusunda sunduğu aktiviteler çok çeşitli değildir. Bu parkın ayrıcalığını, Eskişehir' in kimliğine katkıda bulunan Porsuk Nehri'nin etrafında konumlanmış olması oluşturmaktadır. Su ile arasında engel bulunmayan bir park tasarımı mevcuttur. İskelelerle temas artırılmıştır. Kayıklarla deneyimleme imkânı sunmaktadır. Çocuklar dışında genç ve yetişkinler bir arada bulunabilmek- 
tedir. Aydın Arat Parkı, Tablo 5'te belirtilen çocuk parkları temel tasarım kriterlerinden doğru malzeme kriteri hariç diğer tasarım kriterlerini (erişilebilirlik, güvenlik, çeşitlilik ve çekicilik, kontrol, karma kullanım, sosyalleştirici, peyzaj, kullanıcı talepleri) karşılamaktadır. Doğru malzeme için sentetik malzemeler yerine ahşap ya da benzeri doğal malzemeler tercih edilmelidir ancak Aydın Arat Parkı, Dede Korkut Parkı ve Eti Parkı'nda olduğu gibi bu kriteri sağlayamamıştır.

Diğer küçük ölçekli parklara ait fotoğraflar Şekil 10' da ifade edilmiştir, Geleneksel oyun alanlarından meydana gelmiştir.

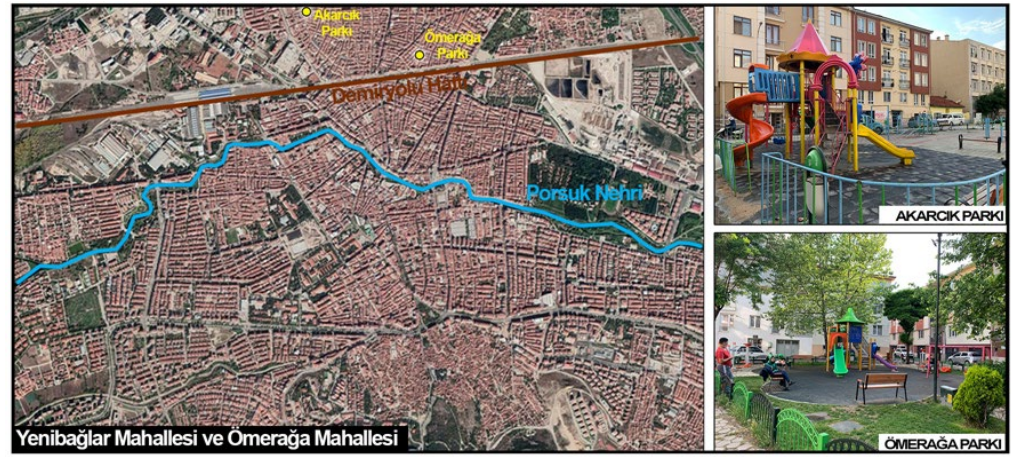

Şekil 10. Eskişehir kent merkezindeki geleneksel oyun alanlarına ait fotoğraflar (Kaynak: Atıc 2020, Şekildeki fotoğraflar yazarlar tarafindan çekilmiştir; Google Earth, 2020)

Şekil 10'da gösterilen Akarcık Parkı ve Ömerağa Parkı, binaların arasında kentle temasın kısıtlı olduğu, yeşil alan kurgusunun bulunmadığı ve farklı alışkanlıklara imkân tanımayan bir durum sergilemektedir. Dolayısıyla, Tablo 5'te belirtilen çocuk parkları temel tasarım kriterlerinden sosyalleştirici, peyzaj, kullanıc talepleri kriterlerini karşılarken; erişilebilirlik, güvenlik, çeşitlilik ve çekicilik, kontrol ve karma kullanım kriterlerini karşlayamamaktadır. Bu sebeple Akarcık Parkı ve Ömerağa Parkı sağlıklı kentler bağlamında olumlu gösterilecek örnekler arasında değildir.

Elde edilen veriler; oyun alanı kategorilerine göre ve çocuk parklarının tasarlanmasındaki kriterlere göre analiz edilmiştir. Bu analizler bulgular bölümünde tablolar halinde ifade edilmiştir.

\section{Bulgular}

Kentsel Mekânda Çocuk Alanları ve Özellikleri bölümünde, Tablo 2'de oyun alanı kategorileri ifade edilmişti. Bu ifadeye göre edinilen bilgiler doğrultusunda Eskişehir kent merkezinde ele alınan parklar analiz edilerek Tablo 6'da ifade dilmiştir. 
Tablo 6. Oyun Alanı Kategorilerine Göre Analiz (Tablo yazarlar tarafindan oluşturulmuştur)

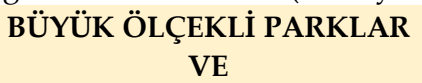

OYUN ALANLARI

\begin{tabular}{|c|c|c|c|c|c|c|c|}
\hline Parklar & $\begin{array}{l}\text { Eti } \\
\text { Park1 }\end{array}$ & $\begin{array}{l}\text { Dede } \\
\text { Korkut } \\
\text { Parkı }\end{array}$ & $\begin{array}{l}\text { Kanlı } \\
\text { Kavak } \\
\text { Park1 }\end{array}$ & $\begin{array}{l}\text { Hamam } \\
\text {-yolu } \\
\text { Caddesi } \\
\text { Parkı }\end{array}$ & $\begin{array}{l}\text { Aydın } \\
\text { Arat } \\
\text { Parkı }\end{array}$ & $\begin{array}{l}\text { Ömerağa } \\
\text { Parkı }\end{array}$ & $\begin{array}{l}\text { Akarcık } \\
\text { Parkı }\end{array}$ \\
\hline $\begin{array}{l}\text { Geleneksel } \\
\text { oyun } \\
\text { alanları }\end{array}$ & $\checkmark$ & $\checkmark$ & $\checkmark$ & $\checkmark$ & $\checkmark$ & $\checkmark$ & $\checkmark$ \\
\hline $\begin{array}{l}\text { Çağdaş } \\
\text { çocuk oyun } \\
\text { alanları }\end{array}$ & & $\checkmark$ & & $\checkmark$ & & & \\
\hline $\begin{array}{l}\text { Macera } \\
\text { oyun } \\
\text { alanları }\end{array}$ & $\checkmark$ & & & $\checkmark$ & & & \\
\hline $\begin{array}{l}\text { Özel } \\
\text { öğrenme } \\
\text { alanları }\end{array}$ & & & & & & & \\
\hline
\end{tabular}

TEMSİLI

GELENEKSEL

OYUN ALANI

Tablo 6'ya göre, tüm parklarda geleneksel oyun alanlarının bulunduğu görülmüştür. Ancak çocuklar meraklıdır ve geleneksel oyun alanları bu merak duygusunu karşılayacak donanımlara sahip değildir. Eti Parkı, Dede Korkut Parkı ve Hamamyolu Caddesi Parkı, geleneksel oyun alanları dışında macera ve çağdaş oyun alanları da bulundurduğu için çocukların fiziksel ve sosyal taleplerine daha çok karşılık vermektedir.

Kentsel Mekânda Çocuk Alanlanı ve Özellikleri bölümünde, Tablo 5'te çocuk parklarının tasarlanmasındaki temel kriterler ifade edilmişti. Bu ifadeye göre edinilen bilgiler doğrultusunda Eskişehir kent merkezinde ele alınan parklar analiz edilerek Tablo 7'de ifade edilmiştir.

Tablo 7. Çocuk Parklarının Tasarım Kriterlerine Göre Analizi (Kaynak: Friedberg, 1982; Uysal, 2013, s. 1-3)

\begin{tabular}{|c|c|c|c|c|c|c|c|}
\hline \multirow[b]{2}{*}{ Parklar } & \multicolumn{5}{|c|}{$\begin{array}{c}\text { BÜYÜK ÖLÇEKLİ PARKLAR } \\
\text { VE } \\
\text { OYUN ALANLARI }\end{array}$} & \multicolumn{2}{|c|}{$\begin{array}{c}\text { TEMSİLI } \\
\text { GELENEKSEL } \\
\text { OYUN ALANI }\end{array}$} \\
\hline & $\begin{array}{l}\text { Eti } \\
\text { Park1 }\end{array}$ & $\begin{array}{l}\text { Dede } \\
\text { Korkut } \\
\text { Parkı }\end{array}$ & $\begin{array}{l}\text { Kanlı } \\
\text { Kavak } \\
\text { Parkı }\end{array}$ & $\begin{array}{l}\text { Hamam- } \\
\text { yolu } \\
\text { Caddesi } \\
\text { Park1 }\end{array}$ & $\begin{array}{l}\text { Aydın } \\
\text { Arat } \\
\text { Parkı }\end{array}$ & $\begin{array}{l}\text { Ömer- } \\
\text { Ağa } \\
\text { Parkı }\end{array}$ & $\begin{array}{l}\text { Akarcık } \\
\text { Parkı }\end{array}$ \\
\hline Erişilebilirlik & $\checkmark$ & $\checkmark$ & $\checkmark$ & $\checkmark$ & $\checkmark$ & $\checkmark$ & $\checkmark$ \\
\hline Güvenlik & $\checkmark$ & $\checkmark$ & $\checkmark$ & $\checkmark$ & $\checkmark$ & $\checkmark$ & $\checkmark$ \\
\hline
\end{tabular}




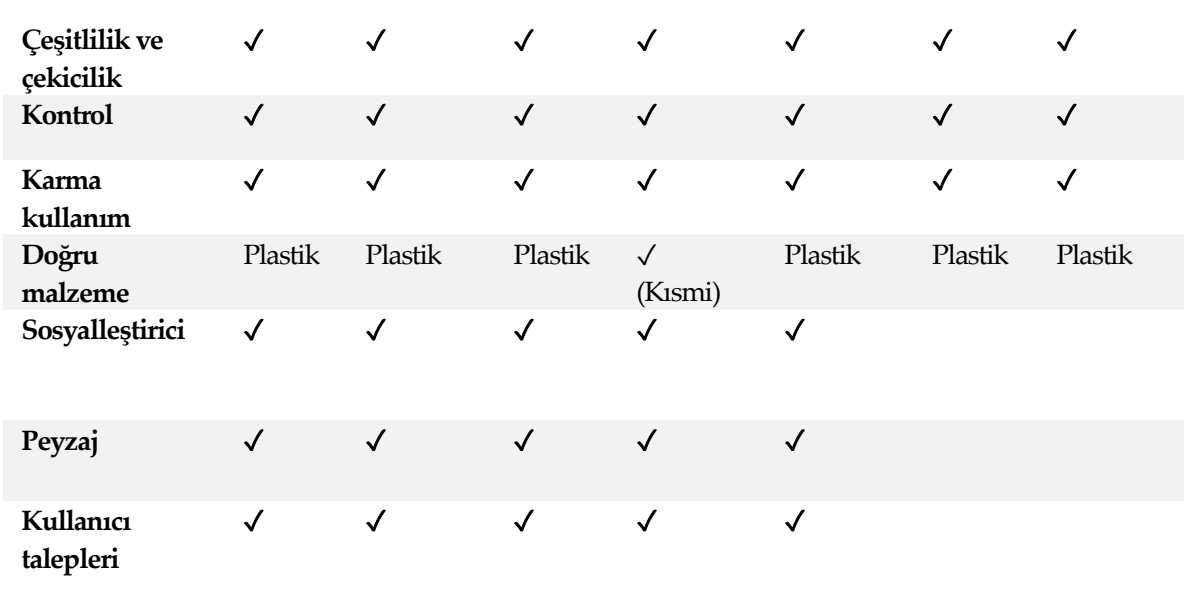

Tablo 7'ye göre, çocuk parklarının tasarlanmasındaki temel kriterlerden birçoğunun karşlanmasına rağmen genel problemin doğru malzeme kriterinin sağlanamamasının olduğu görülmüştür. Doğru malzeme kullanımı için sentetik malzemeler yerine ahşap ya da benzeri doğal malzemeler tercih edilmelidir. Malzeme kullanımına yönelik kriterler, Türk Standartları Enstitüsü (TSE EN 1176) tarafından belirlenmiştir. Tüm bilgiler ve analizler sonucunda edinilen bilgiler doğrultusunda ortak bir analiz tablosu oluşturulmuştur. Bu analiz Tablo 8' de ifade edilmiştir.

Tablo 8. Eskişehir Kent Merkezindeki Seçilen Çocuk Oyun Alanlarının Genel Analizi (Tablo yazarlar tarafından oluşturulmuştur)

\begin{tabular}{|c|c|c|c|c|c|c|c|}
\hline \multirow[b]{2}{*}{ Parklar } & \multicolumn{5}{|c|}{$\begin{array}{c}\text { BÜYÜK ÖLÇEKLİ PARKLAR } \\
\text { VE } \\
\text { OYUN ALANLARI }\end{array}$} & \multicolumn{2}{|c|}{$\begin{array}{l}\text { TEMSİLI } \\
\text { GELENEKSEL } \\
\text { PARK }\end{array}$} \\
\hline & $\begin{array}{l}\text { Eti } \\
\text { Park1 }\end{array}$ & $\begin{array}{l}\text { Dede } \\
\text { Korkut } \\
\text { Park1 }\end{array}$ & $\begin{array}{l}\text { Kanlı } \\
\text { Kavak } \\
\text { Parkı }\end{array}$ & $\begin{array}{l}\text { Hamam- } \\
\text { yolu } \\
\text { Caddesi } \\
\text { Park1 }\end{array}$ & $\begin{array}{l}\text { Aydın } \\
\text { Arat } \\
\text { Parkı }\end{array}$ & $\begin{array}{l}\text { Ömer- } \\
\text { Ağa } \\
\text { Parkı }\end{array}$ & $\begin{array}{l}\text { Akarcık } \\
\text { Park1 }\end{array}$ \\
\hline $\begin{array}{l}\text { Aktivite } \\
\text { Çeşitliliği }\end{array}$ & 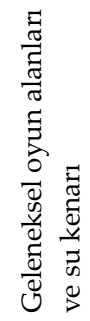 &  & 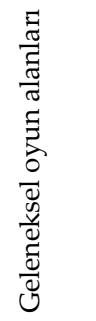 & 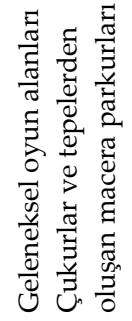 & 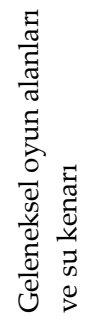 & 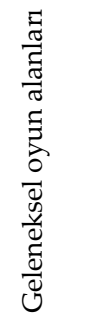 &  \\
\hline
\end{tabular}




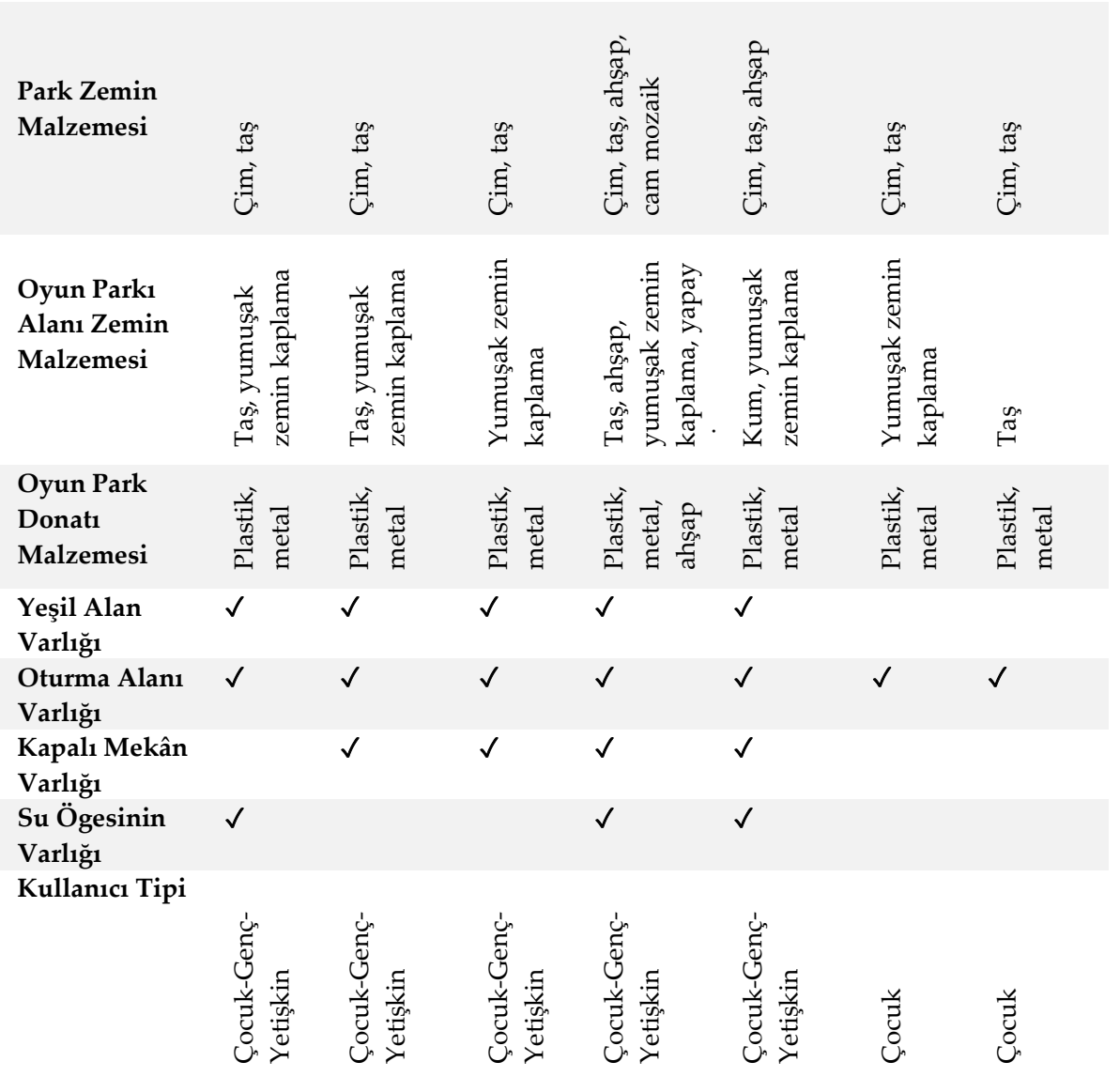

Yapılan analizler doğrultusunda, Eskişehir kent merkezinde çocuk oyun alanlarının genelinin geleneksel oyun alanlarından oluş̧uğu ifade edilebilir. Sokak aralarında küçük ölçekli geleneksel oyun alanlarının bulunduğu görülmüştür. Bu alanların kullanımı ve sunduğu aktivite çeşitlilikleri oldukça kısıtlıdır. Eskişehir kent merkezinde birçok aktiviteye imkân sunan çocuk oyun alanlarının demiryolunun güneyinde kalan kısmında konumlandığı görülmektedir. $\mathrm{Bu}$ alanda Porsuk Nehri'nin de varlı̆̆ı çocuk oyun alanlarının farklılaşmasına imkân tanımaktadır. Ancak, sadece geleneksel oyun alanları, bu alanlarda da küçük ve sınırlı sayıda oyuncak bulunduğu için demiryolunun kuzeyinde kalan kısımda böyle olumlu bir durumdan bahsedilememektedir. 


\section{Tartışma ve Sonuç}

Sağlıklı kent bağlamında, kent de yaşayan tüm bireylerin sağlıklı bir yaşam sürmesi için gerekli olan "açık hava fiziksel aktiviteleri ile aktif yaşam modeli" giderek önemli bir hale gelmiştir. Çünkü pasif yaşam ve hareketsizlik, küresel bir sağlık sorunu haline gelmiştir. Son yıllarda sağlık problemlerinin daha oluşmadan önlenmesi "Koruyucu Tıp" adı altında büyük önem kazanmıştır. Bu da tam olarak "yaşam tarzımız ve yaşadığımız mekanlarla" ilişkilidir. Kentin en küçük kullanıcıları olan çocuklar, fiziksel aktivitelerini oyun ile gerçekleştirmektedir. Bu çalışmada da çocukların kentteki aktivite ve sosyalleşme alanı olarak oyun alanları sağlıklı kent kriterleri üzerinden analiz edilmiştir. Örneklem alanı olarak, son yıllarda kentleşme politikaları ile cazibe merkezi haline gelen Eskişehir kenti seçilmiştir. Yapılan çalışmada, Eskişehir kent merkezinde çocuk oyun alanlarının, önceden tanımlanmış yazın taramasinda var olan (Friedberg, 1982; Uysal, 2013, s. 1-3) standart kriterlere göre oluşturulmadığı; aksine kullanılan malzemelerin, oyun elemanlarının, peyzaj ve diğer donatıların gelişi güzel seçimlerle oluşturulduğu saptanmıştr. Mevcutta var olan geleneksel oyun alanlarınun, sadece basit fiziksel aktivitelere yönelik olduğu görülmüsstür. Diğer yandan, çocukların yaratıcılık, keşfetme ve deneyimleme ihtiyaçlarına cevap verebilecek çeşitlilikte, farklılıkta ve yeteri kadar donanımda olmadığı saptanmıştır. Ayrıca kent merkezinde, farklı yaş grupları için, farklı düzenlemelerin yapılmadığı tespit edilmiştir. Kent merkezinin genelinde küçük ölçekli çocuk oyun alanlarının nitelikleri sorgulanabilir olmakla birlikte, son yıllarda yapılan büyük ölçekli temalı park düzenlemelerinin içerisinde yer alan çocuk oyun alanlarının çeşitliliğinin ve niteliğinin daha yüksek olduğu görülmektedir. Kentin farklı uçlarında yer alan "Sazova Bilim, Sanat ve Kültür Parkı ile Kent Park" farklı temalarla, kentlinin rekreatif ihtiyaçlarını karşılarken, çocuklara da farklı mekânsal olanaklar sunmaktadır. Bu parklar merkeze uzak olmaları nedeniyle erişimi zor olduğu için, gündelik hayatın içerisinde sık kullanımı olamamaktadır. Hamamyolu'nun 2018 yılında yeniden düzenlemesi için yapılan "Hamamyolu Urban Deck" proje uygulaması, kentin odağında farklı aktivitelerle çocuklara yeni oyun alanları sunmaktadır. Bu parkların da zaman içerisinde ihtiyaçlara ve standartlara uygun olarak güncellenmesi, koşullarının iyileştirilmesi gerekmektedir. Çocukların gündelik hayatta sıklıkla kullanabilecekleri, yaşadıkları mekanlara en yakın mahalle ölçeğinde çocuk oyun alanlarının, nitelik ve nicelik yönünden istenen kriterlere uygun, çocukların keşfetmesine ve deneyimlemesine olanak tanıacak, sağlıklı malzemeler ve 
uygun detaylandırmalarla oluşturulmuş olması yerel yönetimlerin en önemli görevlerinden biridir. Çocuklar için kentlerde oluşturulacak nitelikli ve yeterli sayıda oyun alanı tasarımı, sağlıklı bir toplum yaratmanın en önemli kriterlerinden biridir.

\section{Değerlendirme ve Öneriler}

Bugünün çocuklarının, yarının yetişkinleri olacağı unutulmamalıdır. Çocukların ve gençlerin gelişimine katkıda bulunacak çözümler üretilmelidir. Bu sebeple sağlıklı bir kent olmak için öncelikle çocuklara verilen önemin artması gerekmektedir. Parklardaki bu eksikliğin giderilmesi, çocukların gelişiminde daha sağlıklı bir süreç oluşturacaktır. Bu şekilde, toplumun en küçük bireyi olan çocuklar, topluluğa oluşturacak bu döngüde daha sağlıklı bir durum ortaya koyacaktır. Bu bağlamda birtakım öneriler geliştirilmiştir.

Öneriler:

- Var olan geleneksel oyun alanlarındaki oyuncakların malzeme yönünden çeşitliği artırılabilir. Bu şekilde malzeme deneyimi imkânı yakalanacaktır. Çocukların algılamasında ve mekân deneyimlemesinde farkındalık yaratıp algılamasını artırmak için; farklı doku ve renkte zemin malzemesi oluşturulabilir. Bu alanlarda doğal yeşil alanların varlı̆̆ına önem verilmelidir. Ayrıca sadece çocuklara yönelik değil aynı zamanda yetişkinlerin de oturabileceği alanlara imkân tanımalıdır. Bu şekilde güvenlikli olma hali artacaktır.

- Sokakların arabalara terkedilmek yerine yeniden eğlenceli hale gelmesi için çalışılabilir. Bu bağlamda daha çok duyurularla gönüllü katılımlar meydana getirilebilir. Sokaklarda bulunan duvarlar, kaldırımlar renklendirilerek ve farklı malzemelerle eğlenceli hale getirilebilir.

- Woonerf ve Homezone olarak uluslararası uygulanan çalışmalar ülkemizde ve şehrimizde yaşayan, kaliteli, sağlıklı ve güvenlikli sokaklar kapsamında yeniden ele alınarak değerlendirilebilir.

Çocuk oyun alanları ve parkları bağlamında Türkiye'den örnek oluşturabilecek olumlu park örneği olarak İstanbul Moda Sahili, çocuk oyun alanı ve parkı Şekil 11'de ifade edilmiştir. 


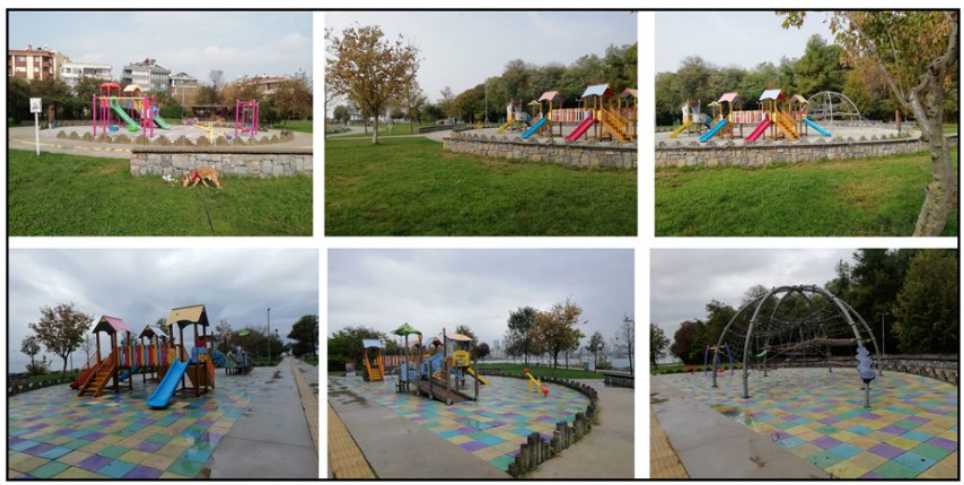

Şekil 11. İstanbul Moda Sahili Çocuk Oyun Alanı ve Parkı (Kaynak: Öztürk 2020, Şekildeki fotoğraflar yazarlar tarafından çekilmiştir)

Yapılan çalışma kapsamında Tablo 6, Tablo 7 ve Tablo 8'de yapılan analizlerin Moda Sahili Çocuk Parkı için birlikte analiz edilmesi Tablo 9'da ifade edilmiştir. Moda Sahili Çocuk Parkı'nın, geleneksel ve macera oyun alanlarını bünyesinde barındıran bir park olduğu görülmüştür. Deniz kenarında konumlanması ve peyzaj olarak doğal alanın içerisinde yer alması kullanıcı çeşitliliği için bir fırsat oluşturmaktadır. Ayrıca park donatı ve zemin malzemesi olarak çeşitlilik gösteren parkın, kullanıcılarının çocuklarla birlikte yetişkinlerin kontrolüne de imkân tanıyan bir şekilde kurgulanması olumlu bir tavır olarak görülmüştür.

Tablo 9. Moda Sahili Parkı için çalışma kapsamında yapılan analizlerin uyarlanması (Tablo yazarlar tarafından oluşturulmuştur)

\begin{tabular}{|c|c|c|c|c|c|}
\hline \multicolumn{2}{|c|}{$\begin{array}{l}\text { Oyun Alanı } \\
\text { Kategorilerine } \\
\text { Göre Analiz }\end{array}$} & \multicolumn{2}{|c|}{$\begin{array}{l}\text { Çocuk Parklarının } \\
\text { Tasarlanmasındaki } \\
\text { Kriterlere Göre Analiz }\end{array}$} & \multicolumn{2}{|c|}{ Genel Analiz } \\
\hline $\begin{array}{l}\text { Geleneksel } \\
\text { oyun } \\
\text { alanları }\end{array}$ & $\checkmark$ & Erişilebilirlik & $\checkmark$ & $\begin{array}{l}\text { Aktivite } \\
\text { çeşitliliği }\end{array}$ & $\begin{array}{l}\text { Geleneksel oyun } \\
\text { alanları } \\
\text { Ve Macera içerikli } \\
\text { oyun alanı }\end{array}$ \\
\hline $\begin{array}{l}\text { Çağdaş } \\
\text { çocuk oyun } \\
\text { alanları }\end{array}$ & Yok & Güvenlik & $\checkmark$ & $\begin{array}{l}\text { Park zemin } \\
\text { malzemesi }\end{array}$ & Çim, taş, ahşap, \\
\hline $\begin{array}{l}\text { Macera } \\
\text { oyun } \\
\text { alanları }\end{array}$ & $\checkmark$ & $\begin{array}{l}\text { Çeşitlilik ve } \\
\text { çekicilik }\end{array}$ & $\checkmark$ & $\begin{array}{l}\text { Oyun park1 } \\
\text { alanı zemin } \\
\text { malzemesi }\end{array}$ & $\begin{array}{l}\text { Taş, ahşap, } \\
\text { yumuşak zemin } \\
\text { kaplama }\end{array}$ \\
\hline $\begin{array}{l}\text { Özel } \\
\text { öğrenme } \\
\text { alanları }\end{array}$ & Yok & Kontrol & $\checkmark$ & $\begin{array}{l}\text { Oyun park } \\
\text { donatı } \\
\text { malzemesi }\end{array}$ & $\begin{array}{l}\text { Plastik, metal, } \\
\text { ahşap }\end{array}$ \\
\hline
\end{tabular}




\begin{tabular}{|lllll}
\hline & $\begin{array}{l}\text { Karma } \\
\text { kullanım }\end{array}$ & $\checkmark$ & $\begin{array}{l}\text { Yeşil alan } \\
\text { varlığ1 }\end{array}$ & $\checkmark$ \\
\hline $\begin{array}{l}\text { Doğru } \\
\text { malzeme }\end{array}$ & $\begin{array}{l}\checkmark \\
\text { (K1smi) }\end{array}$ & $\begin{array}{l}\text { Oturma } \\
\text { alanı } \\
\text { varlığ1 }\end{array}$ & $\checkmark$ \\
\hline Sosyalleştirici & $\checkmark$ & $\begin{array}{l}\text { Kapalı } \\
\text { mekân } \\
\text { varlığ1 }\end{array}$ & Yok \\
\hline Peyzaj & $\checkmark$ & $\begin{array}{l}\text { Su ögesinin } \\
\text { varlığ1 }\end{array}$ & $\checkmark$ \\
\hline $\begin{array}{l}\text { Kullanıcı } \\
\text { talepleri }\end{array}$ & $\checkmark$ & $\begin{array}{l}\text { Kullanicı } \\
\text { tipi }\end{array}$ & $\begin{array}{l}\text { Çocuk-genç- } \\
\text { yetişkin }\end{array}$ \\
\hline
\end{tabular}

Çocuk oyun alanları ve parkları bağlamında yurt dışından örnek oluşturabilecek olumlu park önerileri Tablo $10^{\prime}$ da ifade edilmiştir.

Tablo 10. Yurt Dışı Olumlu Park Önerilerinden Fotoğraflar (Kaynak: Iveta, 2017)

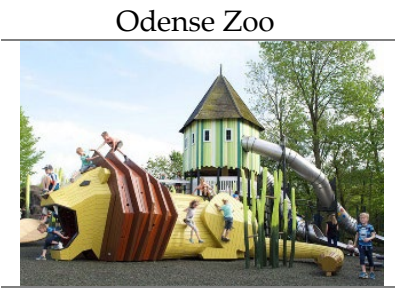

Cosmos

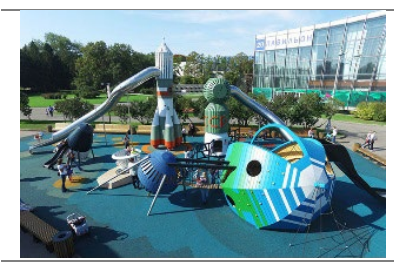

Theater Playground

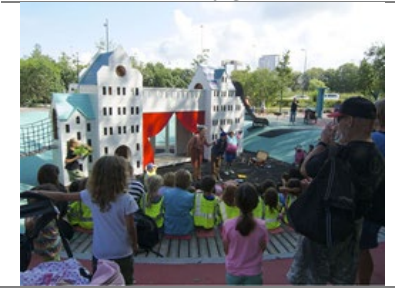
Kristineberg Slottspark

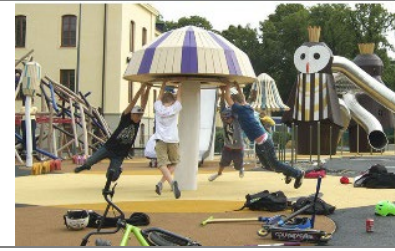

The Alphabet Playground
The Bermuda Triangle

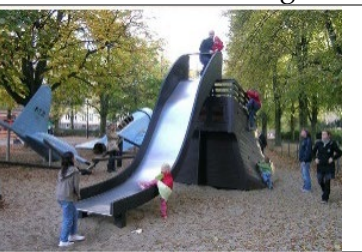

The Snake In The Meld-

gÅrd Forest



The Parrot

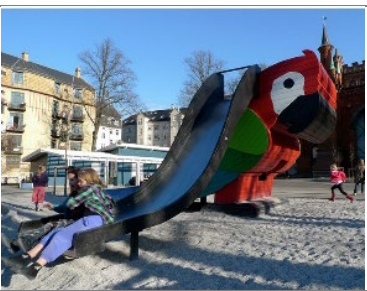

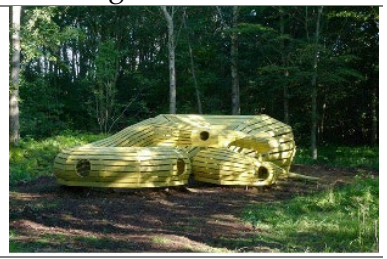

Gyllins Drivhus

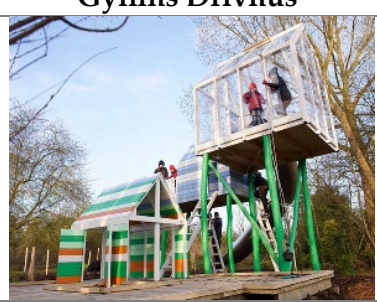


Tablo 10'da görüldüğü üzere, çocuk oyun parkları, oyun alanı kategorisine göre tek bir çeşit altında toplanmamıştır. Her park kendi içerisinde; geleneksel oyun alanları, çağdaş çocuk oyun alanları, macera oyun alanları ve özel öğrenme alanlarının farklı şekillerde bir araya gelmesiyle oluşmuştur. Çocuk oyun alanı zemin malzemesine bakıldığında; kum, çakıl, doğal çim, yapay çim, taş, ahşap, plastik, yumuşak zemin ve sert zemin malzemelerinin olduğu görülmüş̧ür. Oyun donatı malzemelerine bakıldığında; plastik, metal, ahşap, halat kullanımlarının olduğu görülmüştür. Bu örneklere bakıld1ğında yerel örneklerden farklı olarak kendisine has bir kurgusunun olduğu görülmüştür. Örneğin Tablo 10'da görülen "The Bermuda Triangle” bölgede gizemli bir şekilde kaybolan gemi ile çocuklarda keşif yapma duygusunu uyandırırken "Theater Playground" oyun alanı tiyatro etkinlikleriyle çocukların bir arada faaliyet göstermesine imkân tanımaktadır. 


\section{Extended Abstract}

\section{Analysis of Playgrounds in Children's Park in The Context of Healthy City: Example of Eskisehir City}

\author{
Elif Atic1 \\ ORCID: 0000-0001-7163-2660
}

\author{
Ayşen Çelen Öztürk \\ ORCID: 0000-0002-1821-2402
}

Cities are important centers of collective life. The continuation of social life in a healthy way is possible by gaining the awareness of urban culture. The acquisition of urban consciousness is a long process that starts from childhood. Childhood is the first period in which an individual begins to make sense of life and gives direction to his character. Passing this period in a healthy way is important for both the individual and the society. For this reason, the activities that children do in contacting and communicating with others come to the fore. Therefore, in order to provide this communication environment, the urban spaces where the childhood process is spent from the beginning should be well designed. The streets were sufficient as places where children grew up and played in cities until the 20th century; however, it has become dangerous with the increase in population and the intensification of vehicle traffic. This situation has increased the need for children's playgrounds in children's parks and the importance for the design of these areas. Needs must be met for a healthy city. For this reason, the design of children's playgrounds is a necessary step for a healthy city. Therefore, it is aimed to examine the design criteria of children's playgrounds in accordance with healthy city criteria. Eskişehir city center was chosen as an example embodying this goal. The study is a qualitative research because it examines a situation that exists in society. Evaluation study according to its purpose; According to the method, it can be considered as a field research. It is a field study according to the environment in which it is made. Within the scope of the study, literature review (documentary literature review), mapping, on-site determinations and observations were used.There is a study (Uz and Çabuk, 2006) on children's playgrounds in Eskişehir in 2006. With this study, it has been seen that children's areas where children spend their time are insufficient, especially in city centers. Therefore, children's playgrounds in the city center between 
the years 2006-2020 were discussed. In this review, it has been seen that the existing traditional playgrounds are for simple physical activities only. On the other hand, it has been determined that children are not sufficiently equipped to meet theneeds of creativity, exploration and experience. In addition, it has been determined that different arrangements are not made for different age groups in the city center. As a result, within the scope of this study, children's playgrounds in the city center of Eskişehir were analyzed, their compliance with the ideal design criteria according to the concept of "Healthy City" was examined, and suggestions were presented for the development of these areas.

In the context of a healthy city, the "active life model with outdoor physical activities", which is necessary for all individuals living in the city to lead a healthy life, has become increasingly important. Because passive life and inactivity have become a global health problem. In recent years, prevention of health problems before they occur has gained great importance under the name of "Preventive Medicine". This is exactly related to "our lifestyle and the places we live in". Children, who are the smallest users of the city, perform their physical activities with games. In this study, children's playgrounds as an activity and socialization area in the city were analyzed on the basis of healthy city criteria. The city of Eskişehir, which has become a center of attraction with its urbanization policies in recent years, was chosen as the sample area. In the study, it was found that children's playgrounds in Eskişehir city center were not created according to the standard criteria existing in the predefined literature review (Friedberg, 1982; Uysal, 2013, p. 1-3); on the contrary, it was determined that the materials used, game elements, landscape and other equipment were created by random choices. It has been observed that the existing traditional playgrounds are for simple physical activities only. On the other hand, it has been determined that children are not sufficiently equipped to meet the needs of creativity, exploration and experience. In addition, it has been determined that different arrangements are not made for different age groups in the city center. Although the qualities of small-scale children's playgrounds are questionable throughout the city center, it is seen that the variety and quality of children's playgrounds within the large-scale theme park arrangements made in recent years are higher. Located at different ends of the city, the "Sazova Science, Art and Culture Park and the City Park" meet the recreational needs of the citizens with different themes and offer different spatial opportunities for children. Since these parks are far from the center and difficult to access, they cannot be used frequently in daily life. The "Hamyolu Urban Deck" project implementation, which was made for the reorganization of Hamamyolu in 2018, offers children new playgrounds with different activities in the center of the city. These parks also need to be updated 
over time in accordance with the needs and standards, and their conditions should be improved. It is one of the most important duties of local governments that children's playgrounds, which can be used frequently in daily life, are created with healthy materials and appropriate detailing, in accordance with the desired criteria in terms of quality and quantity, and which will allow children to explore and experience. Designing a qualified and sufficient number of playgrounds for children in cities is one of the most important criteria for creating a healthy society.

\section{Kaynakça/References}

Çanakçıŏlu, N. G. (2012). Çocukta mekân algısının gelişimi ve mekânsal imge zenginliği bakmmndan malzemenin önemi. Mimarlkta Malzeme(2), 1-8.

Özerk, G. B. (2014). 21. Yüzyll kentinde çocuk olmak... Mimarlar Odası Adana Şubesi Dergisi(16), $14-16$.

Özservet, Y. Ç. (2017, Ağustos). 1990'lardan bu yana çocuk dostu bir şehir: 10 Ekim 2019 tarihinde

Fano.https://www.researchgate.net/publication/265709118_1990\%27lardan_bu_yana_ Cocuk_Dostu_bir_Sehir_Fano adresinden erişildi.

Özservet, Y. Ç., ve Doğan, E. (2014). Creating a public space for children in the city's center: The case of Kasimpasa-Turabibaba Library in İstanbul. Şehir merkezinin yeniden buluşu (s. 114). içinde Bursa: TMMOB Mimarlar odası Bursa Şubesi. doi: 10.13140/2.1.3240.2880

Öztürk, A. Ç. (2010). Bir sosyal hizmet projesi: "zihinsel engelli çocuklar rekreasyon parkı". Eskişehir Osmangazi Üniversitesi MühendislikMimarlk Fakültesi Dergisi, 23(2), 137-149.

Aksoy, Y. (2011). Çocuk oyun alanları üzerine bir araşırma İstanbul, Isparta, Eskişehir, Erzurum, Kayseri, Ankara, Zonguldak ve Trabzon illeri örneği. İstanbul Aydn Üniversitesi Dergisi, 3(11), 82-106.

Alpan, A. (2015). Mekân sahipliliği için mekân çocuklarla birlikte üretmek: Eskişehir odunpazarı için bir model önerisi. İdealkent, 6(17), 202-251.

Başaran, İ. (2007). Sağlıklı kentler kavramının gelişiminde sağlıkı kentler projesi. Dokuz Eylül Üniversitesi Sosyal Bilimler Enstitïsü Dergisi, 9(3), 207-229.

Bartlett, S. (2002). Building better cities with children and youth. Environment and Urbanization, 14(2), 3-10. doi:10.1177/095624780201400201

Barton, H., ve Tsorou, C. (2005). Sağhlkh şehir planlaması. (T. S. Başkanlı̆ı, Çev.) Türkiye Sağlıkı Kentler Birliği.

Birol, G. (2009). Çocuk dostu kent neresidir? Megaron Balkesir, Mimarlar Odası Balkesir Şubesi, $10-13$.

Bishop, K., ve Marshall, N. (2017). Social interactions and the quality of urban public space. Encyclopedia of Sustainable Technologies, 63-70. doi:https://doi.org/10.1016/B978-0-12409548-9.10177-0

Bourdieu, P. (1984). Distinction: a social critique of the judgement of taste. London \& New York: Routledge. 
Brown, C., Lannoy, A., McCracken, D., Gill, T., Grant, M., Wright, H., ve Williams, S. (2019). Special issue: child-friendly cities. Cities \& Health, 3(1-2), 1-7. doi:10.1080/23748834.2019.1682836

Churchman, A. (2003). Is there a place for children in the city? Journal of Urban Design, 8(2), 99111. doi:10.1080/13574800306482

Emür, S. H., ve Onsekiz, D. (2007). Kentsel yaşam kalitesi bileşenleri arasında açı ve yeşil alanların önemi-Kayseri/Kocasinan ilçesi park alanları analizi. Sosyal Bilimler Enstitüsü Dergisi, 22(1), 367-396.

Ergen, S., ve Çelik, A. (2018). Eskişehir istatistikleri 2017. 06 Eylül 2019 tarihinde http://www.eskisehir.bel.tr/dosyalar/istatisliklerle_eskisehir/2017.pdf adresinden erişildi.

Ermiyagil, M. A., ve Gürçınar, C.S. (2015). Kentsel mekânın gelişiminde çocuk oyun alanlarının rolü: K.K.T.C'de yeni kent Gönyeli örneği. İdealkent, 6(17), 12-45.

Etli, D. P., ve Yamaçı, R. (2015). Çocuklar için sokakların güvenlik koşullarının irdelenmesi: Eskişehir Odunpazarı örneği. Turkish Studies, 10(14), 225-244. doi:http://dx.doi.org/10.7827/TurkishStudies.8997

Gökmen, H. S. (2008). Çocuk dostu kentler oluşturmak. Mimar.ist (Üç Aylık Mimarlk Kültürü̈ Dergisi), 8(28), 49-54.

Gökmen, H. S. (2009). Birlikte oynamak. Mimarlk(347), 47-50.

Gazete, T. R. (1999, Eylül 2). T.C. Resmi Gazete. 05 Ağustos 2019 tarihinde https://www.resmigazete.gov.tr/arsiv/23804.pdf adresinden erişildi.

Harvey, D. (2015). Asi şehirler (4. b.). (A. D. Temiz, Çev.) İstanbul: Metis Yayınları.

Herrington, S., ve Brussoni, M. (2015). Beyond physical activity: the importance of play and nature-based play spaces for children's health and development. Economy and Environment(4), 477-483. doi:10.1007/s13679-015-0179-2

Ünal, M. (2009). Çocuk gelişiminde oyun alanlarının yeri ve önemi. İnönü Üniversitesi Eğitim Fakültesi Dergisi, 10(2), 95-109.

IPA. (2020). General statement. 09 Eylül 2020 tarihinde http://ipaworld.org/about-us/generalstatement/adresinden erişildi.

ISGlobal, B. I. (2018). 5 keys to healthier cities. 02 Mart 2020 tarihinde https://www.isglobal.org/en/ciudadesquequeremos adresinden erişildi.

Iveta. (2017). Danish Company Creates the best playgrounds in the world that even grown ups can't resist. 11.Kasım 2020 tarihinde https://www.boredpanda.com/children-playgroundsmonstrum-denmark/ adresinden erişildi.

Koçan, N. (2012). Çocuk oyun alanlarının yeterliliği üzerine bir araştırma: Uşak kenti Kemalöz Mahallesi örneği. Erciyes Üniversitesi Fen Bilimleri Enstitüsü Dergisi, 28(4), 315-321.

Morval, J. (1985). Çeore psikolojisine giriş. (N. Bilgin, Çev.) İzmir: Ege Üniversitesi Basımevi.

Muhacir, E. A., ve Özalp, A. Y. (2016). Planlama ve tasarım süreçleri bağlamında çocuk oyun alanlarına ilişkin temel kalite kriterlerinin belirlenmesi. Artvin Çoruh Üniversitesi Artoin Çoruh Üniversitesi, 17(2), 220-230.

Murray, J. (1900). Murray's Hand-book Constantinople Brusa, and the Throad. London: John Murray. 
Park, R. E. (2018). Topluluğun örgütlenmesi ve çocuk. R. E. Park, ve E. W. Burgess içinde, Şehir: kent ortamındaki insan dauranışlarmm araştınlmast üzerine öneriler (P. K. Kayalıgil, Çev., s. 145-158). Ankara: Heretik Yayınları.

Peyzax, B. v. (2011,1130). Oyunun çocuk gelişimine etkisi ve çocuk oyun alanlan tasarm kriterleri. 04 Nisan 2020 tarihinde https://peyzax.com/oyunun-cocuk-gelisimine-etkisi-ve-cocukoyun-alanlari-tasarim-kriterleri/ adresinden erişildi.

Ramazan, M. O., ve Özdemir, A. A. (2015). Çocuk oyun alanlarının/parklarının fiziksel özelliklerinin ve kullanıcilarının davranışlarının incelenmesi. Arama Sonuçları, 12(1), 1558-1576.

Rebecchi, A., Buffoli, M., Dettori, M., Appolloni, L., Azara, A., Castiglia, P., Capolongo, S. (2019). Walkable environments and healthy urban moves: urban context features assessment framework experienced in Milan. Sustainability, 11(10), 1-18. doi:10.3390/su11102778

Roitman, S. (2010). Gated communities: definitions, causes and consequences. Urban Design and Planning, 163(1), 31-38.

Rojek, C. (2000). Indexing, dragging and the social construction of tourist sights. C. R. Urry içinde, Touring cultures. transformation of travel and theory (s. 52-74). New York: Routledge.

Seçmen, S. (2016). Kentsel mekan kullanım hakkı ve çocuk. Arkitekt(526), 40-48.

Şişman, E. E., ve Özyavuz, M. (2010). Çocuk oyun alanlarının dağılımı ve kullanım yeterliliği: Tekirdağ örneği. Tekirdağ Ziraat Fakültesi Dergisi, 7(1), 13-22.

Tandoğan, O. (2014). Çocuk için daha yaşanılır bir kentsel mekan: dünyada gerçekleştirilen uygulamalar. Megaron, 9(1), 19-33. doi:10.5505/MEGARON.2014.43534

Unicef. (1989, Kasım 20). Çocuk haklarma dair sözleşme. 09 Nisan 2020 tarihinde https://www.unicef.org/turkey/\%C3\%A7ocuk-haklar\%C4\%B1na-dair-

s\%C3\%B6zle\%C5\%9Fme adresinden erişildi.

Unicef. (2021). Unicef for every child. 02 Nisan 2020 tarihinde https://www.unicef.org/aboutunicef adresinden erişildi.

Uysal, A. B. (2013). Bir kamusal mekan olarak çocuk oyun alanları. 01 Mart 2019 tarihinde https://www.researchgate.net/publication/304576182_Bir_kamusal_mekan_olarak_co cuk_oyun_alanlari adresinden erişildi.

Uz, Ö., ve Çabuk, A. (2006). Çocuk oyun alanlarına ilişkin yeterliliklerinin belirlenmesinde coğrafi bilgi sistemlerinden yararlanılması: Eskişehir örneği. Bilişim Derneği, Yapı ve Kentte Bilişim Konferanst (s. 1-6). Ankara: Bilişim Derneği.

Üstün, B., ve Özkan, C. (2016). Eskişehir Hamamyolu Caddesi'nin Cumhuriyet döneminden günümüze mekansal değişimine yönelik bir araştırma. Balkesir Üniversitesi Fen Bilimleri Enstitüsü Dergisi, 18(2), 54-77.

Yllmaz, S., ve Bulut, Z. (2003). Kentsel mekanlarda çocuk oyun alanlarının yeri ve önemi: Erzurum örneği. Milli Ĕ̆itim Dergisi(158). 